\title{
Effectiveness of Cognitive-Behavioral Therapy with an Islamic Approach on Female High School Students' Social Anxiety
}

\author{
- Zahra Ranjbar ${ }^{1}$-Alireza Manzari Tavakkoli ${ }^{2}$ - Amanollah Soltani ${ }^{3}$ - Najmeh Hajipour $^{4}$
}

- Objective: In this study, the effectiveness of cognitive-behavioral therapy with Islamic approach on social anxiety of the first and second period high school female students in the 2019-2020 school year was investigated.

- Method: The research method was a mixed one (qualitative and quantitative). The first part of the research (preparation of a cognitive-behavioral package with an Islamic approach) was performed qualitatively using the analysis of religious propositions. To investigate the validity of the package, some religious experts were asked to give comments on rightness of traditional readings by scholars and the accordance of the suggested techniques in the Islamic cognitive-behavioral package with the objectives of each session. The quantitative part was of quasi-experimental type consisted of two cognitive-behavioral groups with an Islamic approach and a control group. Among those who referred to the Education Counseling center in Kerman city with a complaint of social anxiety, 36 persons were studied by available sampling method, and 18 subjects were randomly assigned to each group. The data collection tool was the social panic questionnaire of Connor et al (2000). Data analysis was performed using descriptive statistics, univariate analysis of covariance and SPSS-22 software.

- Findings: The findings showed that cognitive-behavioral therapy with Islamic approach significantly reduces students' social anxiety $(\mathrm{P}<0 / 001)$.

- Conclusion: Based on this study, it can be suggested that this treatment be used to reduce students' social anxiety.

Keywords: cognitive-behavioral therapy, Islamic, social anxiety, students

- Citation: Zahra Ranjbar, Alireza Manzari Tavakkoli, Amanollah Soltani, Najmeh Hajipour. (2021). Effectiveness of Cognitive-Behavioral Therapy with an Islamic Approach on Female High School Students' Social Anxiety,Applied Issues in Islamic education, 6(2): 7-30.

Received: 2021/04/10

Accepted: 2021/07/01

1. A Ph.D. Student in Educational Psychology, Faculty of Literature and Humanities ,Islamic Azad University, Kerman Branch, Kerman, Iran.

E-mail: Z. Ranjbar 51214@gmail.com. (iD 0000-0002-1574-2459

2. Corresponding Author: Assistant professor in Department of Educational Management, Faculty of Literature and Humanities, Islamic Azad University, Kerman Branch, Kerman, Iran.

E-mail: a.manzari@iauk.ac.ir. (iD) 000-0002-1573-7748

3. An Assistant Professor in Department of Psychology, Faculty of Literature and Humanities, Islamic Azad University, Kerman Branch, Kerman, Iran.

E-mail: Soltanimani@yahoo.com. (iD 0000-0003-3978-7683

4. An Assistant Professor in Department of Psychology, Faculty of Literature and Humanities, Islamic Azad University, Kerman Branch, Kerman, Iran.

E-mail: hajipour_1359@yahoo.com. (iD 0000-0001-6111-6224 



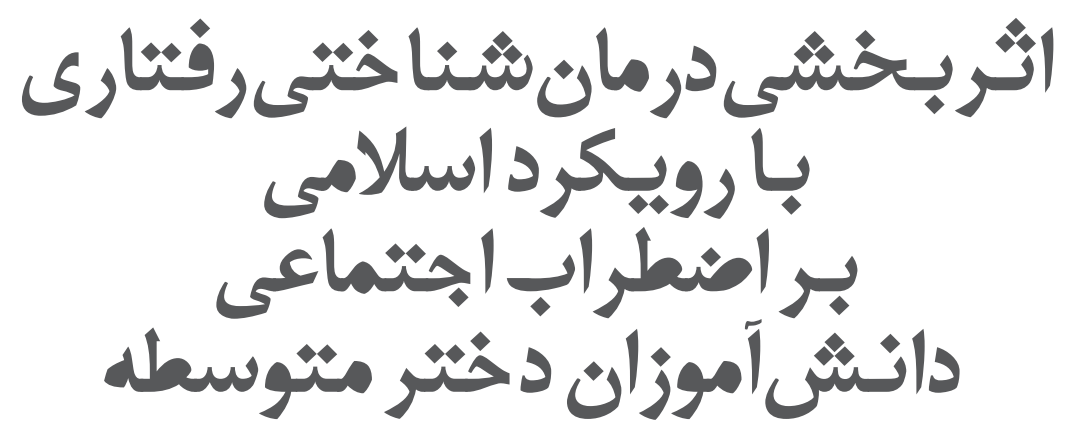

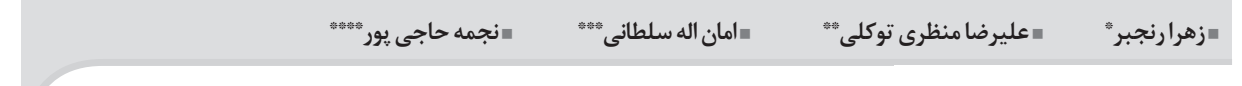

Qـ

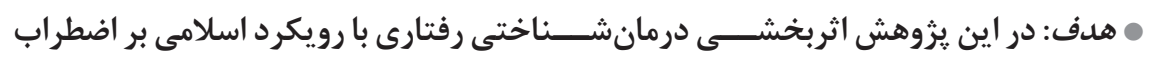

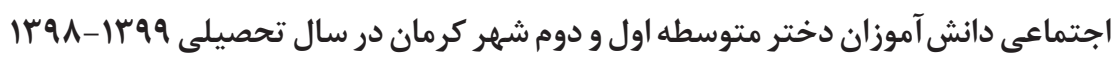

$$
\text { مورد بررسى قرار ترفت. }
$$

• روش: روش تحقيق آميخته اكتشــــافى (كيفى و كمّى) بود. بخش اول يثروهش (تهيه بسته

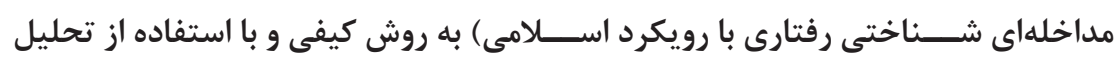

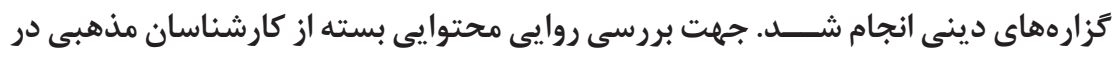

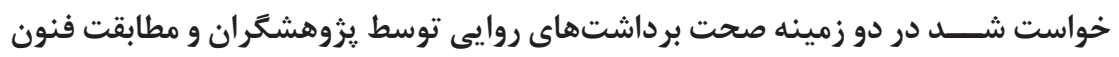

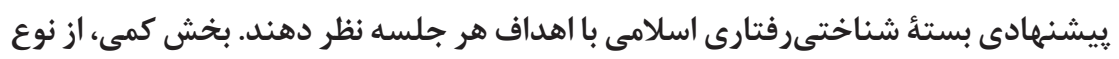

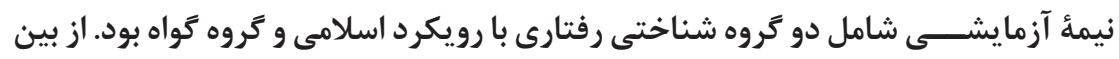

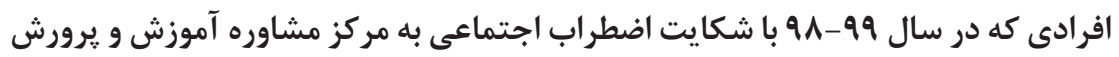
كر مان مراجعه كرده بودند، צץ نفر به روش نمونه \

* دانشجوى دكترى روانشناسى تربيتى، دانشگاه آزاد اسلامى، دانشكده ادبيات و علوم انسانى، دانشكاه آزاد اسلامى واحد كرمان،

E-mail: -z. ranjbar51214@gmail.com. (iD) 0000-0002-1574-2459

*ق*ش نويسنده مسئول: استاديار گروه مديريت آموزشى، دانشكده ادبيات و علوم انسانى، دانشًاه آزاد اسلامى واحد كرمان، كرمان، ايران. E-mail: a.manzari@iauk.ac.ir. (iD) 0000-0002-1573-7748

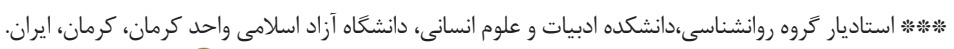
E-mail: soltanimani@yahoo.com. (iD 0000-0003-3978-7683

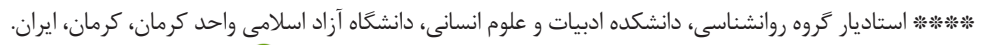

E-mail: hajipour_1359@yahoo.com. iD 0000-0001-6111-6224 
و با بهرهَيرى از كمارش تصادفى \ا نفر در هر كروه بررسى شدند. ابزار جمع آورى دادهها

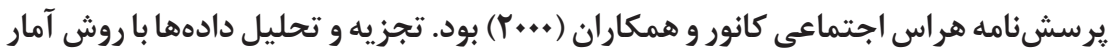

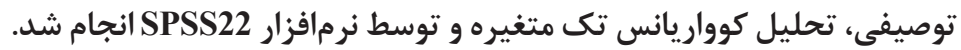
ه يافتهها: نتايج نشان داد درمانشناختى رفتارى با رويكرد اسلامى بهطور معنى دارى موجب إنب

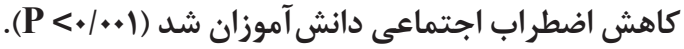

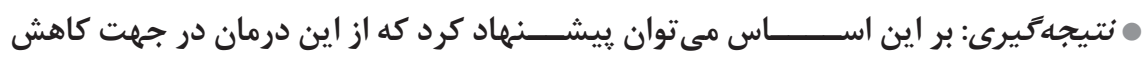
اضطراب اجتماعى دانش آموزان استفاده شود.

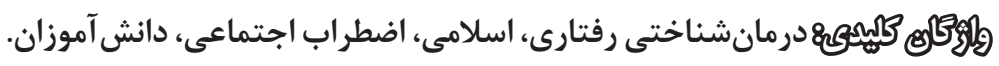

\section{مثلدمه}

اضطراب اجتماعى (Social anxiety) بهنوان ترس مداوم و حاد از موقعيتهاى اجتماعى و عملكردى توصيف مىشود كه در آن موقعيتهاى اجتماعى به دليل احتمال Caetano, Brust-Renc, et al, 2019) تـرس از ارزيابى منفى تهديدآميز تلقى مى

(Neufeld, Palma, يروهشـــران از عامل ارزيابى منفى بهعنوان يك ساز و كار علت شناختى در هراس اجتماعى ياد مى كنند كه بر اساس آن افراد، با ادراك تحريف شدهاى كه دارند، معتقدند ديخران آنها رابهصورت منفى ارزيابى مى كنند (Heimberg,Brozovich, \& Rapee, 2010).

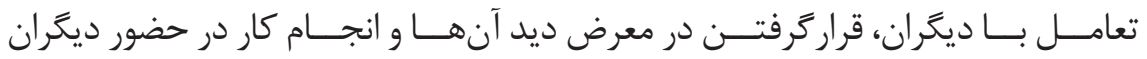
ســـنوع موقعيتى اســت كه براى مبتلايان به اضطراب اجتماعى مشكل ايجاد مى كند. در اين موقعيتها فرد خود را در معرض موشكافى ديخران مىبيند و مىترسد مبادا كارى

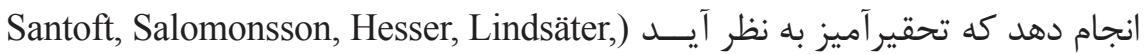
.(Lekander, Kecklund, Öst, \& Hedman-Lagerlöf, 2019 اختــلال اضطراب اجتماعــى يكى از رايجترين اختــلالات اضطرابى و در عين حال عودكنـندهريــن بيمارى در ميان اختلالات اضطرابى اسـتـ. ميزان شــيوع اين اختلال

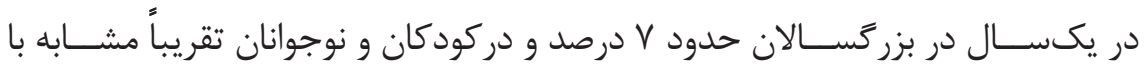
بزركســالان اســت (Neufeld, et al, 2019 (Yuan, Zhu, Qiu, Meng, et al, 2017).

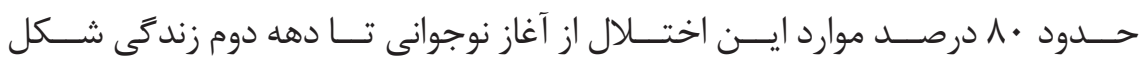




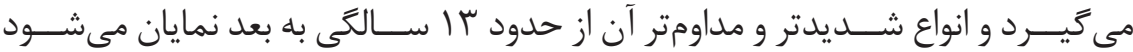
(Richey, Brewer, Sullivan-Toole Strege, et al, 2019) a اختــلال اضطراب اجتماعى درايران كمى بالاتر از كشــورهاى غربى اســت (شــعبانى و مصــدرى، هوس (1). نوجوانانــى كه علائسـم اضطرابى و اختـــلالات را تجربه مى كنـند، طيف وســيعى از مشــكلات اجتماعـى از جمله توانايـى تطابق كمتر با همســالان، يذيــرش يايين بين همســالان و ضعــف در مهارتهاى اجتماعى را نشـــان مىدهند

.(Suvega, Kingery, Davisa, Jones, et al, 2017) عليرغم صدماتى كه اضطراب اجتماعى به حوزه تعاملات اجتماعى وارد مىســازد، كاهى به دليل برداشــت نادرست از اين مقوله و عدم تمايز بين آن و حيا، ويزگى هاى انزواطلبــى، اجتناب از موقعيتهـــاى عملكردى و... عادى تلقـى مى گردد (رمضانى،

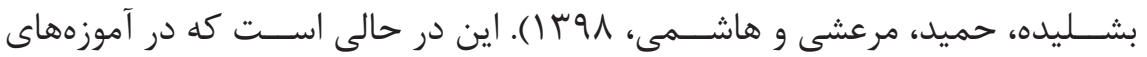

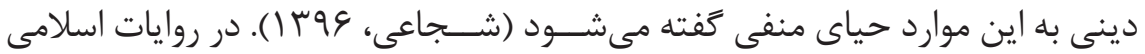

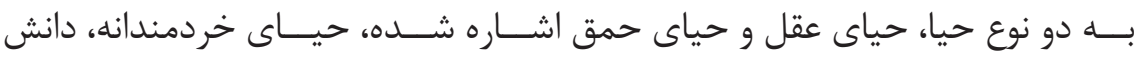

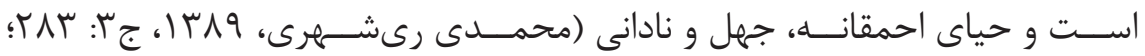

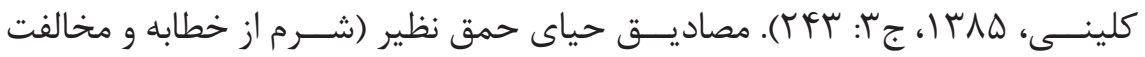
با رســوم غلط، ناتوانى در كَفتخو با افراد غريبه، ناتوانى در توسعه ارتباطات اجتماعى،

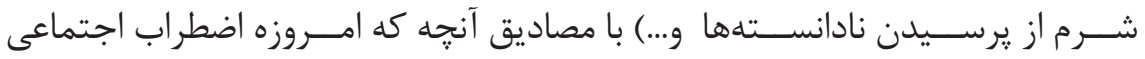

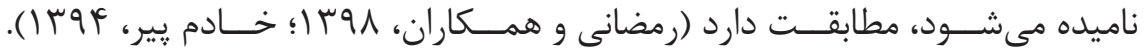
افراد مبتلا به اضطراب اجتماعـى به خاطر نگرانىهايى كه از حضور و نحوه ارزيابى

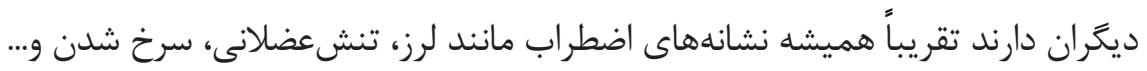
را تجربه مى كنند. از ديد گاه انديشمندان مسلمان اين حالات بهسبب انتظار وقوع ناملايمات در آينده شكل مى گيرد و فرد را به عدم تحرك نفس، به هنغامى كه تحرك آن ضرورى

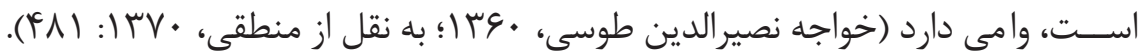
ييامد اين انفعال نيز بـىميلى نســبت به روابط و ايفــاى نقشهاى اجتماعى و بـىثباتى در زند در صورتى يك حضور و نظارت به حياى منفى منجر مى شــود كه ميان فعل و باورهاى 
اجتناب نمى شـــود. آنجهه إين حضور را به عاملى براى اضطراب اجتماعى تبديل مى كند، ضعف و ناراحتى فرد در تحمل فشــار روانى حاضران است. در واقع اين فرد توان تحمل ناظر را ندارد و انجام دادن كار در مقابل ديخران برايش دشواراســت (يسنديده، وجس (). بر همين اساس است كه امام صادق (عليهالسّلام) به حياى ضعف و ناتوانى اشاره فرموده

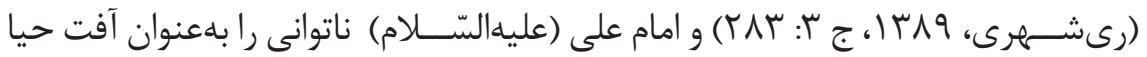

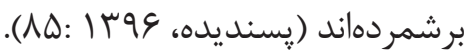

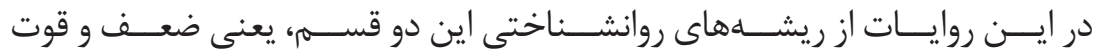

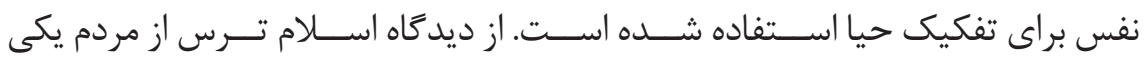

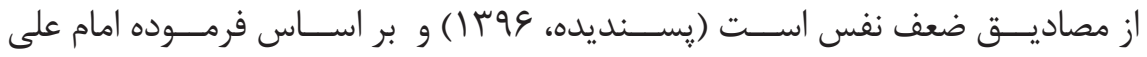

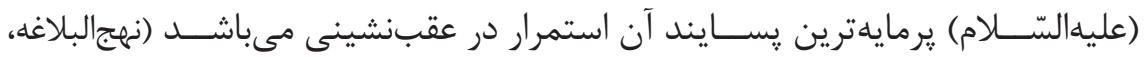

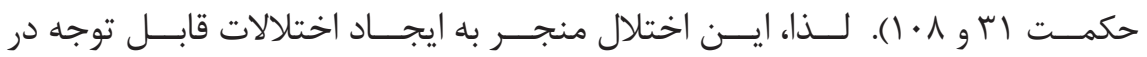

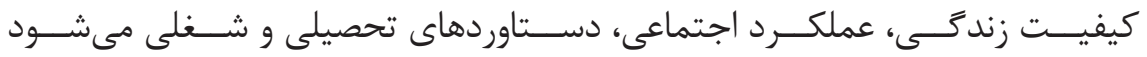
.(Neufeld et al, 2019؛ Nordgreen, Gjestad, Andersson, Carlbring, et al, 2018) يكى از مداخلههاى روان درمانى كه بيشــترين حمايت علمى را به خود اختصاص داده، درمانشناختى رفتارى است (Katz, Cassin, Weerasinghe, \&.Rector, et al, 2019)

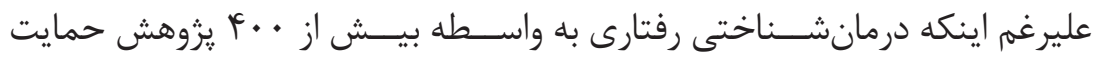

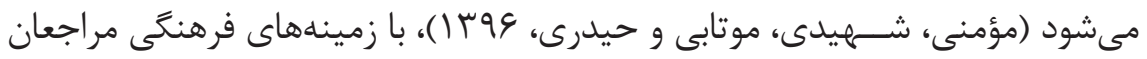

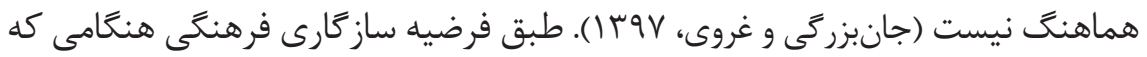
اقدامات درمانى فرهنَ را تكميل مى كنند، درمانهاى روانشناختى مؤثرتر خواهند شد زيرا انســان هايى كه در فرهنگ (Lim, Sim, Renjan, Sam, et al, 2014) رشــد مى كنـند نه تنـها درباره يديدهها متفاوت فكر مى كنـند، بلكه نحوه انديشـــيدن آنها

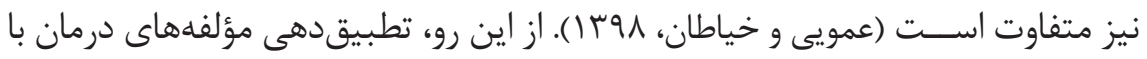
فرهنَ ارباب رجوع، انســجام اقدامات درمانى را افزايش داده و باعث كسب نتايج بهتر مى شود. عليرغم علم به اين موضوع، محققان توجه كمترى به ساز كارى مداخلات درمانى

با اعتقادات مذهبى مراجعين نمودهاند (Yaacob, 2013). غالب صاحبنظران براين باورند كه در ميان اديان الهى، دســتورات اسلام ييرامون بهداشـت جسم، روح و ساير امور، كاملترين فرامين است (ماندنى و سعادت، جو I ). 
التزام به اصول اســلام، موجب رضايت از زندىى و كاهش احســاس تنهايى مىشـــود

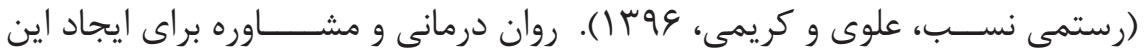

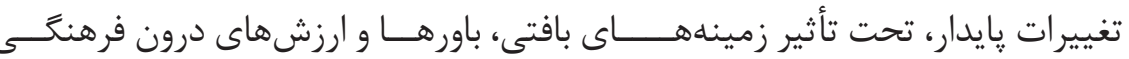

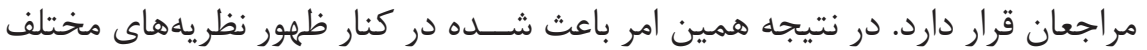

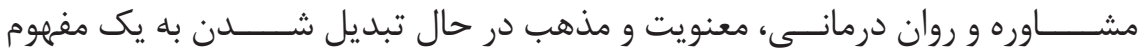

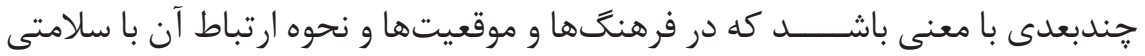

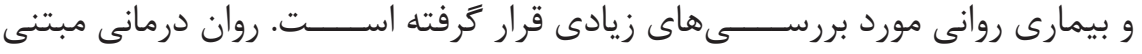

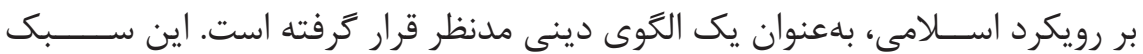

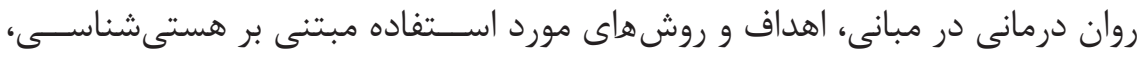
معرفتشناسـى و انسانشناسى اسلامى شــــــل مى كيرد بهَّونهاى كه در آن روان

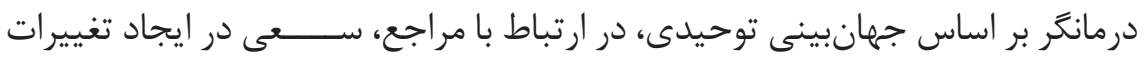

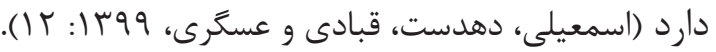
در درمانشناختى رفتارى با رويكرد اسلامى محتوا از متون دينى استخراج و به كار كرفته مىشود و در سطحى فراتر سعى مىشود ابعادى كه در رويكردهاى معاصر مورد

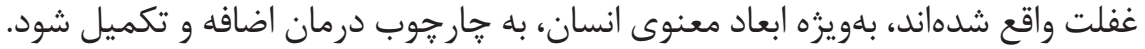
در اين رويكرد بدانديشىها، از طريق اصلاح انديشهها آشكار مى كردد (آمدى، • وج ا : • (ه) )

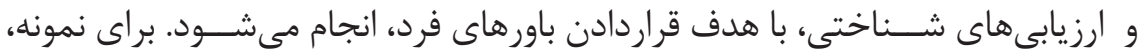

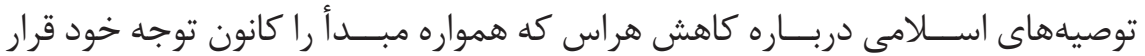

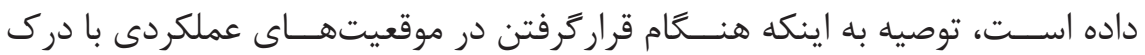

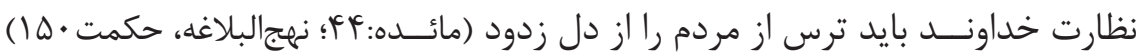

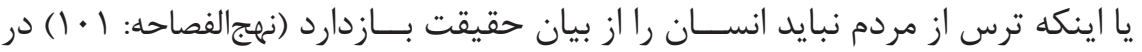

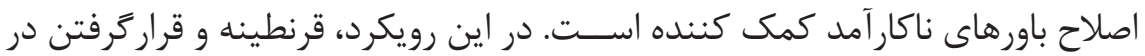

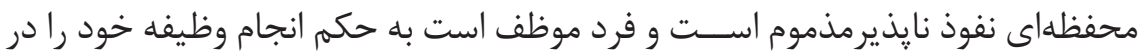
موقعيتهــاى اجتماعى قرار دهد. لذا، از طريق درمان به ضد با موقعيتهاى هراسآور

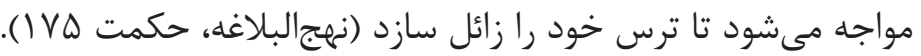

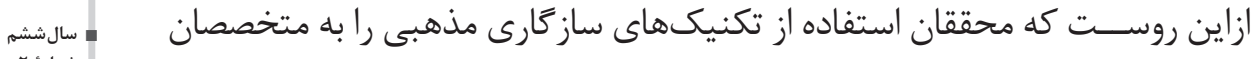


با درمان معنوى و يردازش اطلاعات درحوزههاى اداركى مبدأ، معاد، خود و هستى، براى درمان اختلالات اضطرابى مفيدتر از ســاير تكنيكـهاســت (Lim et al, 2014؛ يعقوبى،

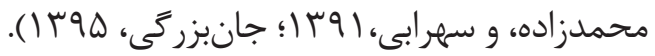

عليرغم اين تأكيدات، مرورى بر تحقيقات انجام شــده مبين آن است كه مداخلات درمانى اغلب در جار جوب رابطه انســان با خود و هستى اطرافش تنظيمم مىشود. نتايج تحقيقات تجربى زير نشان مىدهد كه سرزنش خود با تعدادى از متغيرهاى آسيبشناسى روانى مثل اضطراب اجتماعى و شــرمندگى ارتباط دارد (Gilbert \& Miles, 2000) و

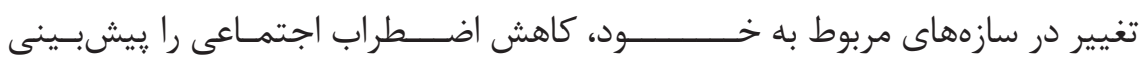
مى كـند (Gregory \& Peters, 2016). مداخله شناختى رفتارى گروهى با تغيير در افكار، احساســات و رفتارها تغييراتى را در اختلال بيمارايجاد مى كند (Neufeld et al, 2019)

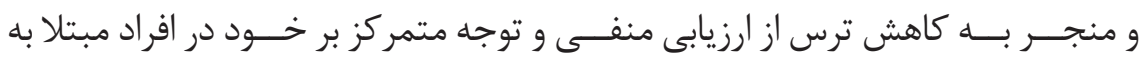
اختــلال اضطراب اجتماعى مى شـــود (هاشــمى نصرت آباد، محمودعلىلـــو و قلىزاده،

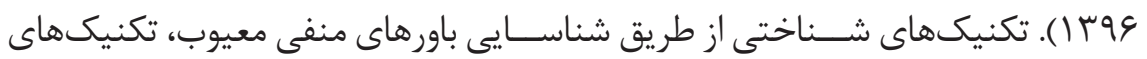
رفتارى از طريق كاهش علائم اضطراب و اصول فراشناختى به وسيله تعديل فراباورهاى مثبت و منفى معيوب در بيماران، منجر به كاهش نشــانغان اضطراب اجتماعى مىشود

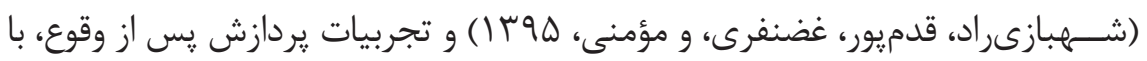
درمان قابل تغيير است(Katz, et al, 2019). نتايج تمرينات باعث بهبود عملكرد اجتماعى در جوانان با اختلالات اضطر ابى شــده (Suvega, et al, 2017) و درمانشناختى رفتارى مبتنى براينترنت يك روش درمانى مناسب براى كاهش اختلال اضطراب اجتماعى است

در درمانشــناختى رفتارى، جنانجه تغييرات شناختى با مبانى اعتقادى فرد همراه

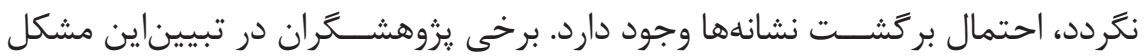
معتقدند كه ممكن اســت طرح درمان مشكل داشته باشد. اما به نظرمىرسد مشكل به مبانــى نظرى طرح درمان نيز بازگردد. در روان درمان گرىهاى امروزى توجه به مبدأ و معاد كه اســاس معنويت انسان اســت بهطور واضح كانون توجه قرار نَخرفته است. براى

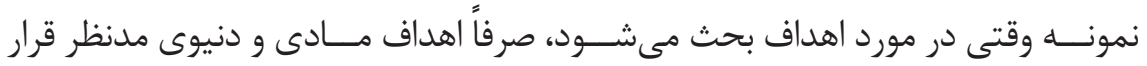


محدود كردن فرايند درمان به دو حوزه هستى و خود، دامنأ اثر روان درمانَرى را

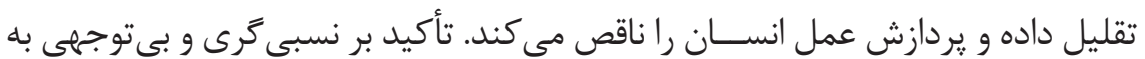
ملاكهاى ارزشى افكار، بى توجهى به عوامل انخيزشى در تشكيل شناختهاو نظام ارزشى

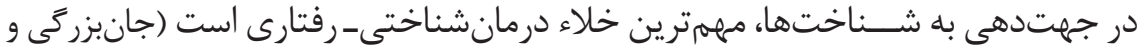
غروىراد، لوجس). اين در حالى اســت كه در درمانشـــاختى رفتارى اسلامى، بايدها و نبايدهاى اخذ شده از مكتب بهعنوان هدفهاى ثابتى مطرح مىشود و دست يابى به يك يايگاه فكرى براى معنادهى و ارزش گذارى صحيح و معنوى براى رفتارها، را امكان يذير

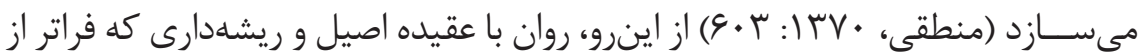
نيازهاى مربوط به حيات دنيوى اســت و شامل حيات بعد از مرگ نيز مى گردد، تغذيه

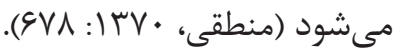
اين ظرفيت گسترده، يزوهشگران حوزه روان درمانى را ترغيب نموده تا با بهرهخيرى از دادههاى مذهب در امر اختلالات روانى اقدام نمايند (انصارى، ه9 با). تغيير يندارههاى نامعتبر در حوزههاى ادراكى خود و هســتى و جايگزينى آن با مفاهيهم معتبر و منطقى، از طريق مكانيزم هســتهاي فعالسازى عقل خدا ســو، مهممترين فعاليت درمانغرانه اين روش اســت. به اينمنظور، انسان از ابعاد مختلف بلويزه بعد مادى و معنوى مورد توجه قرار مى گيرد و مداخلات درمانى بر رســيدن به حسـدى از تعادل و جهت گيرى متعالى، متمركز مىشود (جانبزرگى و غروىراد، Vqr (1). از اين رو، با توجه به اينكه درمانهاى رايج از بطن جوامع غربى برخاســته است، به نظر مىرسد براى اثر گذارى بيشتراين مداخلات در كشورايران، كه فرهنَ اسلامى دارد، لازم است بر مداخلات همسو با مبانى و اصول اسلام تأكيد شود. بهرغم مطالعاتى كه در زمينه تدوين الكوى مفهومى اســلامى درباره متغيرهاى مختلف روانشـــاختى صورت گرفتــه، تاكنون تأثير درمانشـــاختى رفتارى مبتنى بر رويكرد اســلامى بر اضطــراب اجتماعى مورد توجه قرار نخرفته اســت. از اين رو، در يروهش حاضر ميزان اثربخشــى درمانشناختى رفتارى اســلامى بر كاهش اضطراب اجتماعى مورد بررسى قرار كرفته است. در يى اين تحليل و بررسى مشخص مى مشود كه: آيا درمانشناختى رفتارى مبتنى بر رويكرد /سـاملامى بركاهش اضطراب اجتماعى دانشآموزان تأثيرگذار 
در اين يزوهش از روش تحقيق آميخته اكتشـــافى (كيفى و كمّى) اســـفـاده شـــد. در بخش كيفى، از روش توصيف و تحليل موضوعات و زَزارههاى دينى اســتفاده شد و بسته مداخلهاى درمانشناختى رفتارى اضطراب اجتماعى با رويكرد اسلامى تهيه گرديد. در اين يزوهش براى دستيابى به اجماعى قوىتر، يافتههاى متون دينى به كارشناسان مذهبى كه تجربه كار بالينى داشتند، نيز عرضه شد. براى تهيه بسته مداخلهاى شناختى يكى رفتارى اسلامى مراحل زير انجام شد: در ابتدا متونى كه به موضوع اضطراب اجتماعى ارتباط داشتند، استخراج شدند. يس از يافتــن كليد وازمها و مفاهيم مرتبط با اختلال اضطراب اجتماعى، آيات و روايات مربوط به اضطراب اجتماعى در منابع اسلامى استخراج شدند. اين الفاظ عبارتند از شرم، آزرم، كمرويى، حياى حمق، حياى منفى و عزلت گزينى. ســــ بـ با كنار هم حذاشــتن آنها موضوعات مشــابه تعيين شدند و طبقهبندى منسجمى از روايات و نظرات انديشمندان اســلامى، كه به مفهوم اضطراب اجتماعى اشاره داشـــتند، به دست آمد. در مرحله بعد، عوامــل تداوم بخش اختلال اضطراب اجتماعى در آيات، روايات و نظرات انديشـــمندان اسلامى مورد بررسى قرار گرفت و راهبردهاى هراس زدايى متناسب با هر عامل، بهعنوان تكنيكهاى درمانى استخراج شد. با توجه به هدف يثوهش، مداخلهاى تدوين شد كه از ساختار و فرايند درمانشناختى رفتارى تبعيت كند. براى بررســى روايى محتوايى برداشتهاى انجام شده از روايات و مرتبط بودن فنون ييشنهادى با مؤلفههاى استخراج شده، از جهار كارشناس مذهبى روان درمانگر براى اعلام نظر درباره تأثير گذارى فنون ثيشنهادى نظرخواهى شد. بدينمنظور بسته مداخلهاى در اختيار كارشناســان قرار گرفت و با توضيح اهداف و ارائه تعاريف عملياتى محتوا به آنان، از آنها درخواست شد تاميزان هماهنگى محتوا با برداشتهاى انجام شده از روايات اسلامى لـى را مشخص كنند و ديد كاههاى اصلاحى خود را ارائه نمايند. براين اساس يرسشنامهاى

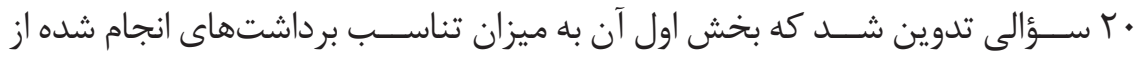
منابع اســلامى با شاخصها و عوامل سبب شــناختى اضطراب اجتماعى كه در جلسات اول تا دهم مورد بحث قرارگرفته، اختصاص يافت. نمرهگذارى به روش ليكرتى انجام شد

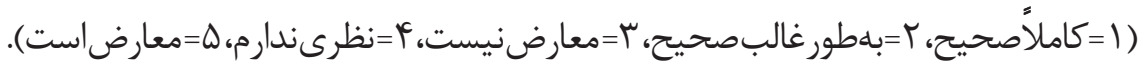


در بخش دوم نيز با طرحاين سؤالات كه تا جه حد تكاليف و فعاليتهاى جلسات اول تا دهم با فنون درمانشناختى رفتارى تناسب دارد؟ ميزان تطابق فنون با درمانشناختى رفتارى مشخص گرديد ( •=عدم تناسب، ه = تناسب كامل). يُ از بازبينى متخصصين

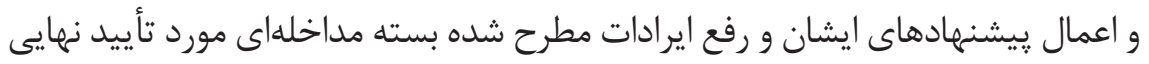
قرار گرفت و روايى محتوايى آن تأييد شد. ميانگين و ميانه نمرات كارشناسان به گزينهها

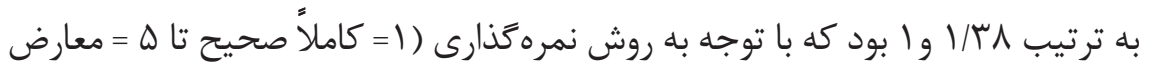
است) به نظر مى رسد حاكى از تأييد صحت برداشتهاست. همجنين ميانگين و ميانه نمرات كارشناسان به ززينههاى مربوط به تطابق فنون با راهكارهاى درمانشناختى رفتارى به

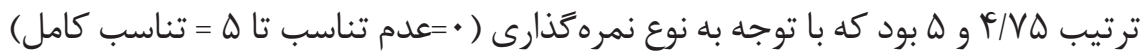
به نظر مىرسد حاكى از تأييد تطابق فنون با اهداف است.

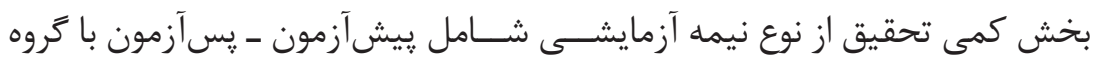
كَواه بـــود. جامعه آمارى دانش آموزان دختر مقاطع متوســطه اول و دوم شــهر كرمان در ســال تحصيلى 99-91"ا بود كه به دليل مشــكلات روانشناختى به مركز مشاوره

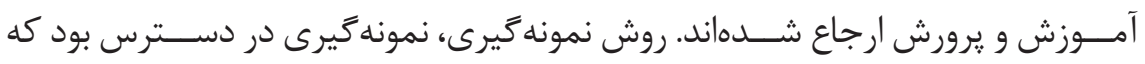

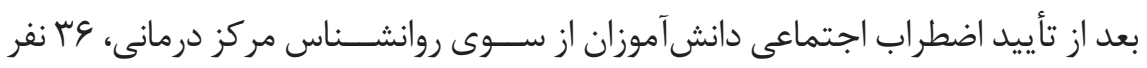
براســاس ملاك هاى ورود و خروج انتخاب شدند. در اين يزوهش عدم مشكل جسمانى،

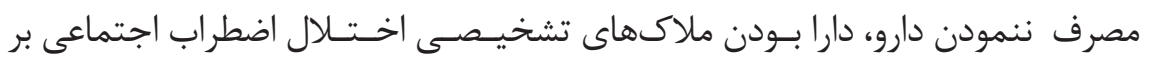
سبه DSM5 بهنوان ملاكهاى ورود؛ ابتلاء به اختلالات ديخر، استفاده از داروهاى روانيزشـكىى حين انجام يزوهش و انجام ندادن تمرينهاى منزل بهعنوان شرايط خروج در نظر گرفته شد.

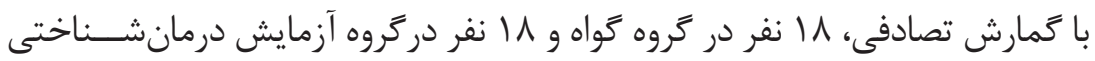
رفتارى اسلامى قرار گرفتند. گروه آزمايش به مدت • ا جلسه باساعته، آموزش با رويكرد اسلامى را دريافت كردند. گروه گواه نيز مداخلهاى دريافت نكردند. يس از اتمام جلسات، دو گروه مقياس هراس اجتماعى را تكميل نمودند تا ميزان تغيير متغير وابســته بررسى شود. همجنين متغيرهاى مداخلهَّر و مزاحم از طريق عدم سوءگيرى محقق، عدم افت

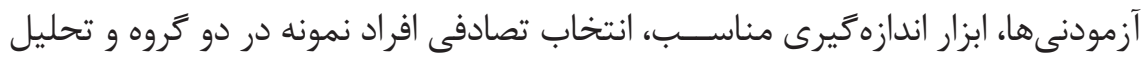




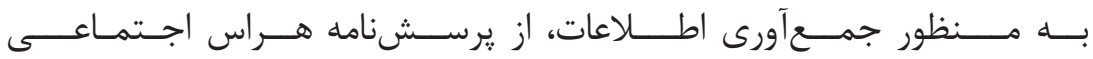
(Connor, Davidson, Churchil, Sherwood, et al, 2000) يك يرسشنامه خودسنجى IV مادهاى است كه سه زيرمقياس ترس (9 ماده)، اجتناب ( Vاده) و ناراحتى فيزيولوزيكى (f ماده) دارد. هر ماده بر يايأة مقياس ليكرت ه درجهاى

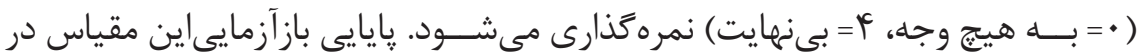

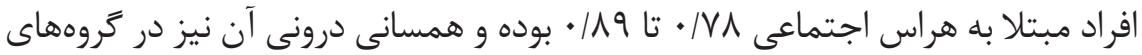

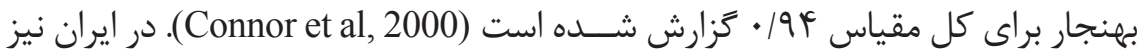

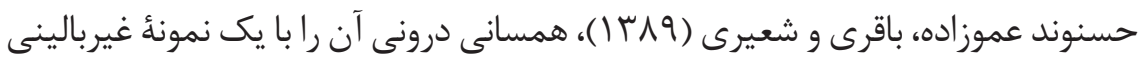

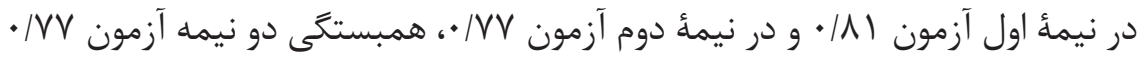

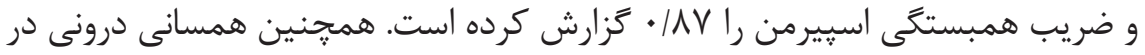

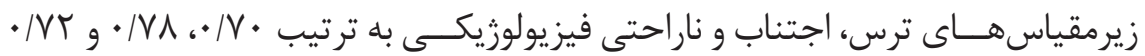

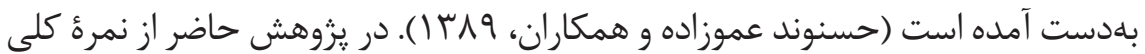
اين مقياس استفاده شد و براى بهدست آوردن اعتبار آن از آلفاى كرونباخ استفاده گرديد.

ضريب آلفا براى اين يرسشنامه سم/ • بلهدست آمد كه نشان از معتبر بودن آن دارد. مبانى نظرى بسته مداخلهاى و تكنيكهاى درمانى مربوطه شامل موارد زير است: در رويكرد اسلامى، شناخت مكانيسمهاى زمينهساز ناكار آمد راهنماى فرايند درمان اســت. بنابراين در Fام اول، باورهاى ناكار آمد زمينهاى مشــخص شده است. دركام دوم شناسايى منشاهاى احتمالى شكل گيرى باورهاى ناكار آمد كنونى در طراحى برنامه درمان مدنظر قرار گرفته و سيس با استفاده از دو راهبرد بازسازى شناختى و عمل به ضد؛ براى

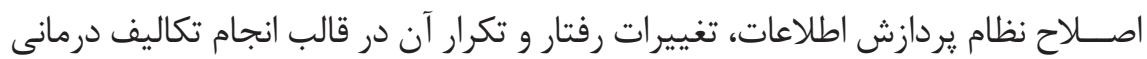
برنامهريزى شده است.

\section{I. مكانيسم زمينهاى ترس از ارزيابى منفى و راهبرد درك حضور ناظر محترم:}

فن: درك حضور خداوند بهعنوان تنها عامل بازدارنده انسان ودرونى ساختن اعتقاد

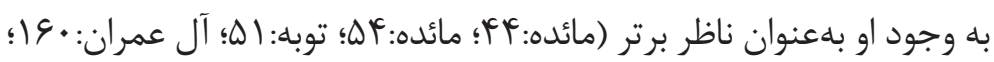

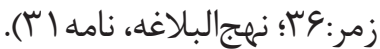

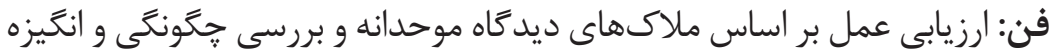

ارتكاب عمل (فيض كاشانى، سبf اق). 
فن: نــَاه موحدانه به ارتباطــات و الخَوَيرى از ســبك ارتباطى حضرت على (عليهالسّلام)؛ (حدادزاده، ؟qج |) اگر در نقش يك معصوم قرار بخيرم، آيا در

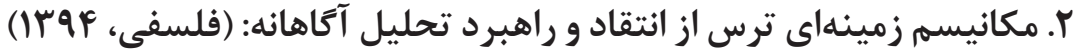
فن: به جالش كشـــيدن روان بنههاى منفى با تدبـــر در نقدها؛ لآيا فكر مى كنى كسى كه زياد مورد انتقاد قرار گيرد آدم بدى است؟ جرا؟《، لآيا رفتارت مورد

$$
\text { تأييد خودت هست؟ جرا؟؟ }
$$

فن: تحليل انتقادات از طريق مشابهتســازى با كلاس درس سيار؛ تأييد بخش درست انتقاد: التقاد را دوباره با جملات متفاوت بيان كند و به منتقد بگويد

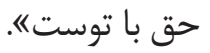

ناديده گرفتن انتقادات نادرست: فرد ظاهراً موافقت خود را نشان مى خدهد اما ييام ناحفتهاش اين است كه: ا|خر جه ممكن است حق با تو باشد، اما من

$$
\text { واقعاً جنين فكر نمى كنمه }
$$

\section{r. مكانيسم زمينهاى توهمخوارى و راهبردايفاى نقش:}

فن: تغيير مســير توجه به اصل كرامت انسـانى (اسرا: • V؛ نهجالبلاغه،خطبه ())،

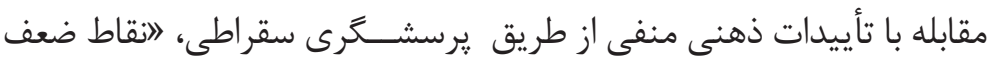
من در موقعيتهاى اجتماعى كدام است؟؟، لكدام نقطه ضعف را مىتوانم با

$$
\text { نشان دادن نبوغ درعرصdهاى ديخر جبران كنه؟؟. }
$$

فن: تصويرسازى ذهنى؛ تغيير شيوه تعامل با ديگران با تجسم صحنههايى كه در

$$
\text { آن فردى خونغرم است (فلسفى، هوس ا ) }
$$

F. مكانيسم زمينهاى تكلف افراطى و راهبرد تنظيم انتظارات واقعبينانه:

فن: مقابله با رؤياى بىنقص بودن با يادآورى تمثيل ״مدادهاى ياك كندار" فن: مقابله با خطاى شناختى توهم استقلال و ترس از عدم قطعيت، يقين به وعده

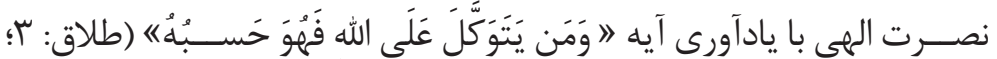




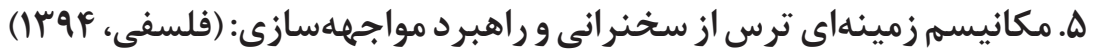
فن: شناسايى عاملترس (تعداد حضار، شنوندكان بيشتر و متخاصمتر، موضوعات

نامأنوس )

فن: سخنرانى در مقابل آينه (فلسفى، ع ب (1). تمرين مكرر و در نهايت مواجهه با

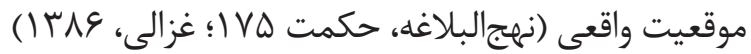

צ. مكانيســـم زمينهاى نقص در مهارتهاى اجتماعى و راهبرد شفقتورزى:

(فلسفى، هوسا؛ نهجالبلاغه، نامه آب).

فن: تمرين اصلاح يك يا دو رفتار اختصاصى نظير بهبود تماس جشمى، صحبت با صداى بلندتر، يادَيرى شيوههاى مباحثه و مكالمه صحيح.

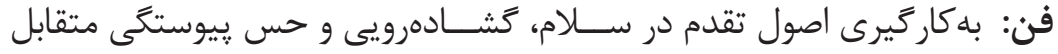

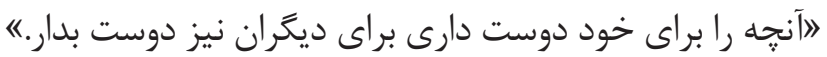
V. مكانيسم زمينهاى افسوس بر كذشته، ترس از آينده و راهبرد اغتنام فرصت:

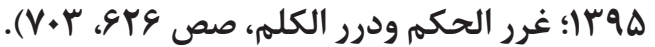

فن: زدودن فكر كذشــته معدوم با به جالش كشــيدن افكار منفى؛ اآيا عملكرد اجتماعىام به همين شدت كه به خاطر مى آورم وحشتناك بود؟ اشواهدم براى اثبات اين موضوع، جيست؟《 اكدام جنبه رويداد برايم آزاردهنده بود؟ نحوه واكنش ديگران، نحوه رفتار خودم يا احساس بدى كه داشتم؟؟. فن: تحليل عوامل نكرانــى موقعيتهاى اجتماعى آينده به دو بخش واقع بينانه و ســاختخىى؛ محاسبه عقلى و يذيرش عوامل نتخرانى غيرقابل تغيير (فلسفى،

فن: اســتفاده از فن جز به جز براى زدودن عوامل نكرانى قابل تغيير (يسنديده،

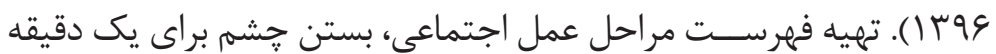
و تفكر ييرامون به يايان رســاندن تمامى مراحل، اندازهگيرى سطح اضطراب كل موقعيت از صفر تا ده، بســتن مجدد جشمهها و تفكر يـيرامون انجام دادن يك مرحله و اندازهزيرى ســـح اضطراب. توصيف سطح اضطراب در مرحله 
فن: اغتنام فرصت؛ \الان خه بايد كرد؟《، "وظيفه من در اين موقعيت جيست؟؟، 》معيارهاى الهى براى انجام|ين تكليف خيسـت؟؟ هاسخ مبتنى برمنطق به

^. مكانيسم زمينهاى اجتناب ازعمل و راهبرد مشــارطه، مراقبـه و محاسبـهـ

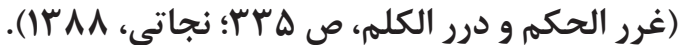
فن: تنظيم سلسله مراتب موقعيتها و فهرست مشكلات فن: تحليــل موقعيتهاى عملكردى و اجتماعـى از حيثاينكه جه مىخواهد؟

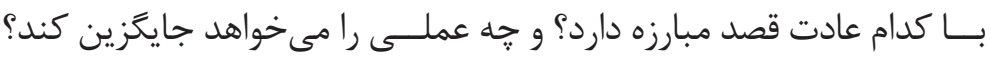

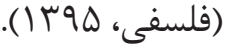

فن: بازنخرى واكنشهاى رفتارى با بهارگيرى تكنيك آينه ذهن و يرسشكرى

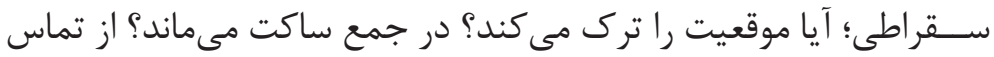

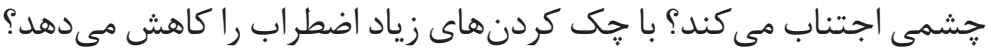
فن: تنظيم قرارداد خود جوش و بازتوانى ترس اجتماعى از طريق تمرين مرتب ورود بـــه موقعيتهاى اجتماعى و تعامل با ديكران با عمل به كامهاى برنامه تهرئ. مواجهd؛ () مشارطه: تهيه يك برنامه مكتوب كه طى يك سلسله مراتب از آغازكرهاى اضطر اب به ترسمحورى مشخصى يرداخته مىشود.

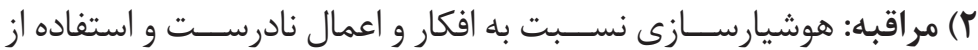

$$
\text { رويارويى تدريجى به سمت اهداف. }
$$

ץ) معاهده: تعهد به برنامه مواجهه روزانه.

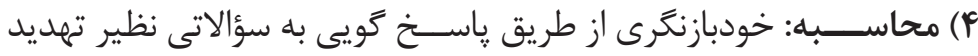

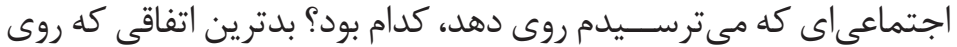

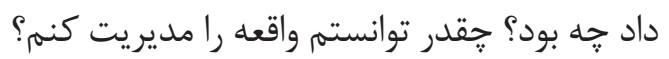

ساختار جلسات محتواى درمانشناختى رفتارى با رويكرد اسلامى در جدول ا ارائه 


\section{فصل فامه (علمى_يزوهشى)}

جدول ا. درمانشناختى رفتارى با رويكرد اسلامى

\begin{tabular}{|c|}
\hline تكاليف \\
\hline • پيش آزمون \\
\hline 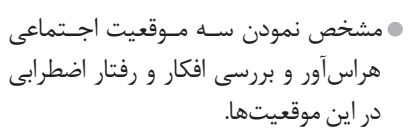 \\
\hline 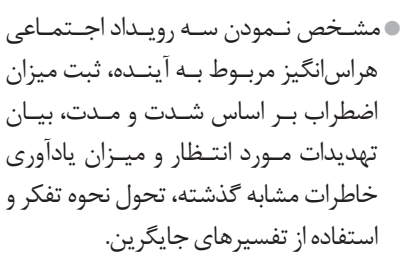 \\
\hline 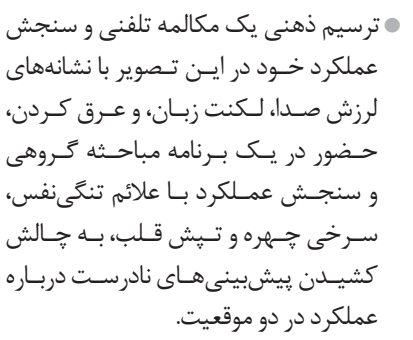 \\
\hline
\end{tabular}

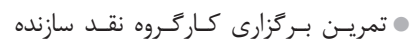

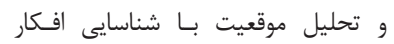

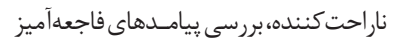
و احتمال وقوع آن و در نهايت تفسيرمنطقى بنى از موضوع.
هناسايى رويدادهاى اجتماعى آينده با اضطراب متوسط،

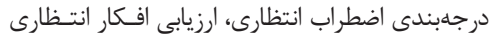

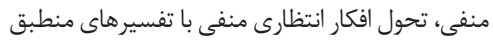

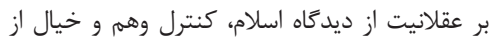
طريق خودنظارت كرى، تمركز برحال و اغترل ونتام فرصت

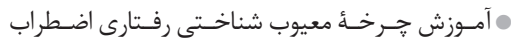

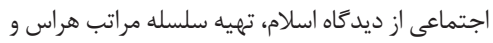

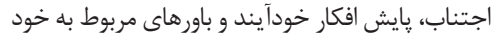

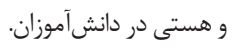

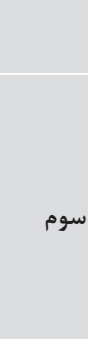

هرويارويى دانشىآموزان با ترسهاى مكالمهاى، شناسايى

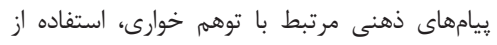

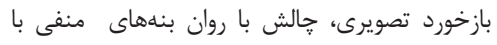

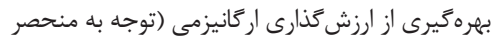

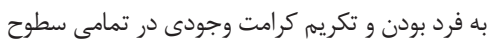

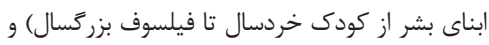

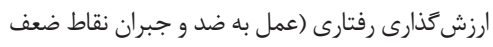
با نشان دادن نبوغ در عرصهماي ديكر) ).

• مواجهه دانـش آموزان بـا موقـعيت اجتماعى اضطرابزا،

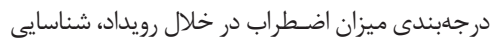

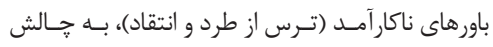

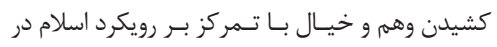

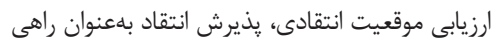

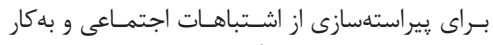

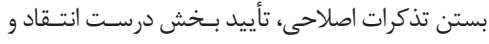
ناديدهانكارى بخش ديخر.

هــــ يك موقعيت اجتماعى هراسانكيز، بــرسى تــرسهاى مـــوقعيتى و انجـام

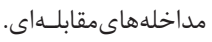

هواجهه دانش آموزان با يكى موقعيت اجتماعى اضطرابزا،

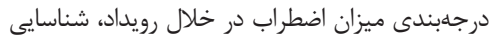

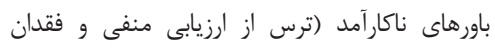

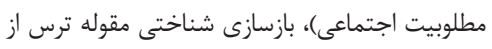

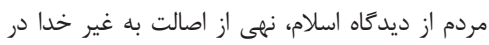

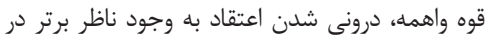
همه حال.
ينجم ششم 


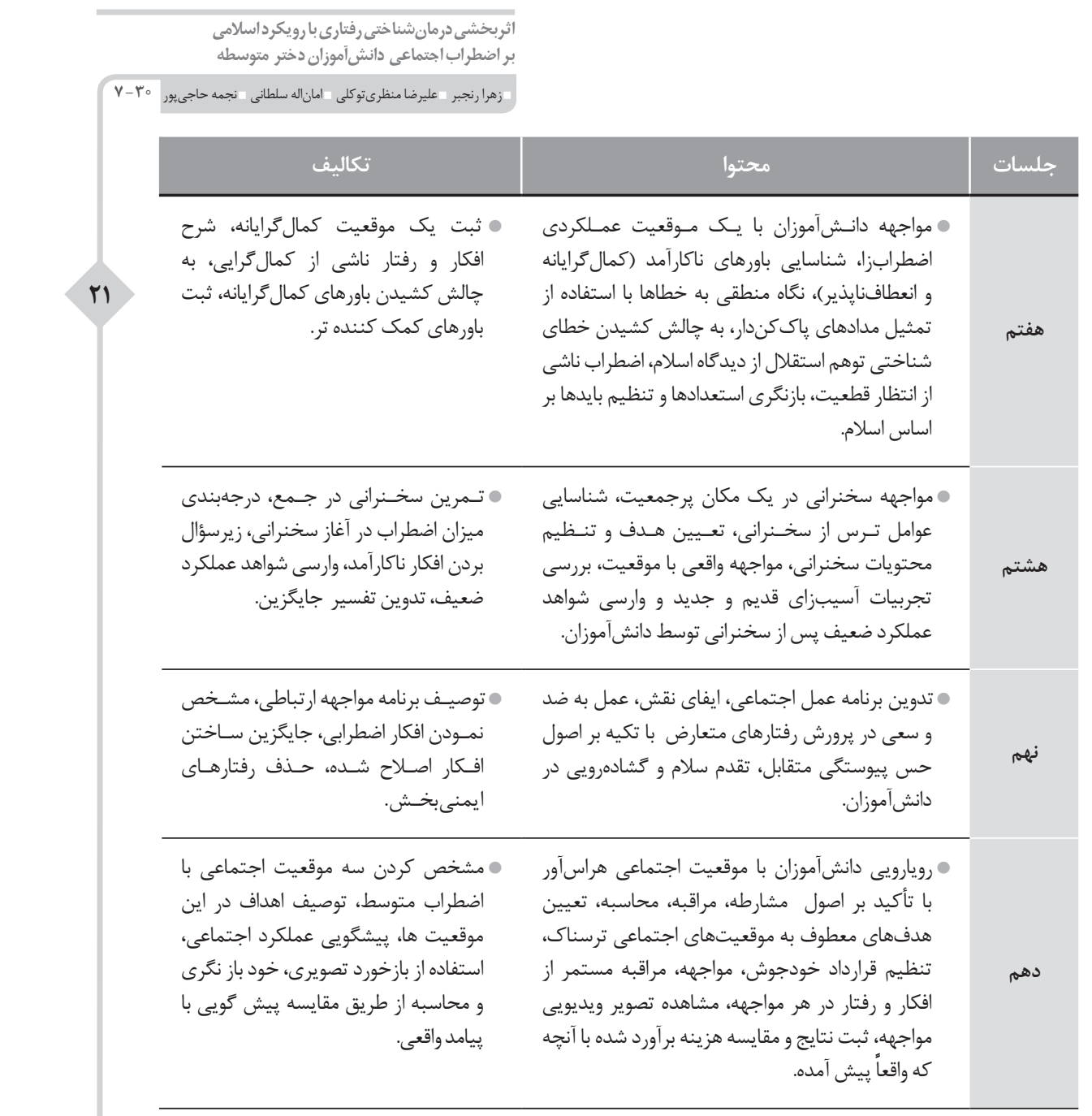

جهت تجزيه و تحليل دادههاى كيفى از روش تحليل موضوعات و گزارههاى دينى و براى تحليل دادههاى كمى از آمار توصيفى، كوواريانس تكى متغيره و نرمافزار SPSS-22

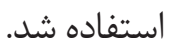

\section{بإنته}

توزيع نمرههاى آزمودنىهاى مورد مطالعه در متغير اضطراب اجتماعى با اســتفاده

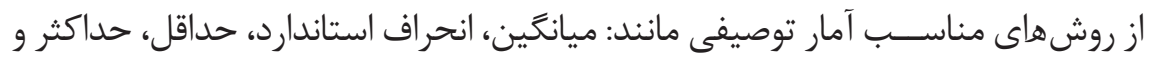

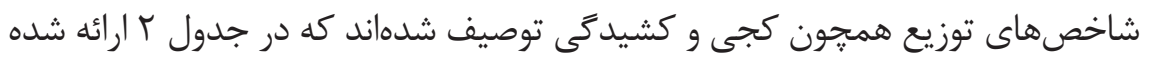


جدول r. شاخصهاى توصيفى متغير يزوهش

\begin{tabular}{|c|c|c|c|c|c|c|c|c|c|}
\hline كشيدكى & كجى & حداكثر & حداقل & استاندارد & ميانَين & مرحله & كروه & متغير & آموزشى بسته \\
\hline$-\cdot / 4 \Delta$ &.$/ 1 \mathrm{~V}$ & $\Delta T$ & TV & $1 / 94$ & TN/FY & پيشآزمون & \multirow{2}{*}{ آزمايش } & \multirow{4}{*}{ اضتماعى } & \multirow{4}{*}{$\begin{array}{l}3 \\
\hat{3} \\
\cdot 3 \\
3 \\
3 \\
\vdots \\
\vdots \\
3 \\
3 \\
3 \\
3 \\
3\end{array}$} \\
\hline$-\cdot / \cdot r$ & ./VG & rV & $r$. & $1 / 14$ & $r V / \cdot \Delta$ & پֶسآزمون & & & \\
\hline$-\cdot / \Gamma \Lambda$ & $\cdot / 1 \Lambda$ & QT & TV & $1 / 99$ & rN/D. & קֶيش آزمون & \multirow{2}{*}{ كنترل } & & \\
\hline$-\cdot / \mu \Delta$ &.$/ 1 T$ & $\Delta T$ & rV & $1 / \Delta V$ & TN/FF & يسآزمون & & & \\
\hline
\end{tabular}

نتايج جدول r، نشــان داد كه شاخصهاى كجى و كشيدگى متغيرها بين بـ بوده كه نشــاندهنده مطلوب بودن وضعيت متغيرها براى انجام آزمون هاى پارامترى است. همجنين در مرحله يِيش آزمون، ميانگينها و انحراف استاندارد متغير اضطراب اجتماعى در گروه آموزش (رويكرد اســلامى) و گروه كنترل، يكســـان مىباشـــند، ولى در مراحل يس آزمون (بعد از مداخله) و يى گيرى، تفاوت زيادى مشــاهده مى شود. با توجه به طرح

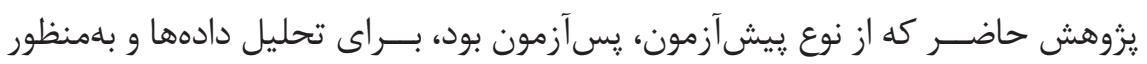
كنترل اثر ييشآزمون و يسآزمون از روش تحليل كوواريانس تكى متغيرى استفاده شد. براى انجام اين آزمون مىبايست مفروضههاى آن مانند، توزيع نرمال متغير وابسته، آزمون همخَنى ماتريس واريانس ـ كوواريانس و آزمون همخَنى واريانس هاى خطا رعايت شـــود. نتايج آزمون كالموكروف اسميرنف نشان داد كه توزيع نمرات در متغير اضطراب اجتماعى بهنجار است (جدول ؟). فرض همگن بودن واريانس ها بهوسيله آزمون لوين بررسى شد كه مفروضه همخونى واريانسها نيز تأييد شـــد (جـــدول ؟). مفروضه مهرم ديخر تحليل كوواريانس، همخونى شــيب خط رَّرسيون است. بررسىها نشان داد تعامل ييشآزمون

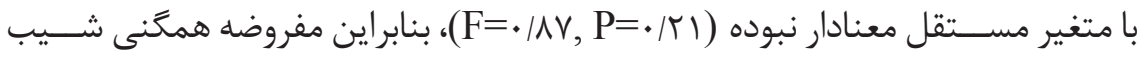
ركرسيون نيز برقرار است. بررسى مفروضهها نشان داد كه استفاده از تحليل كوواريانس 


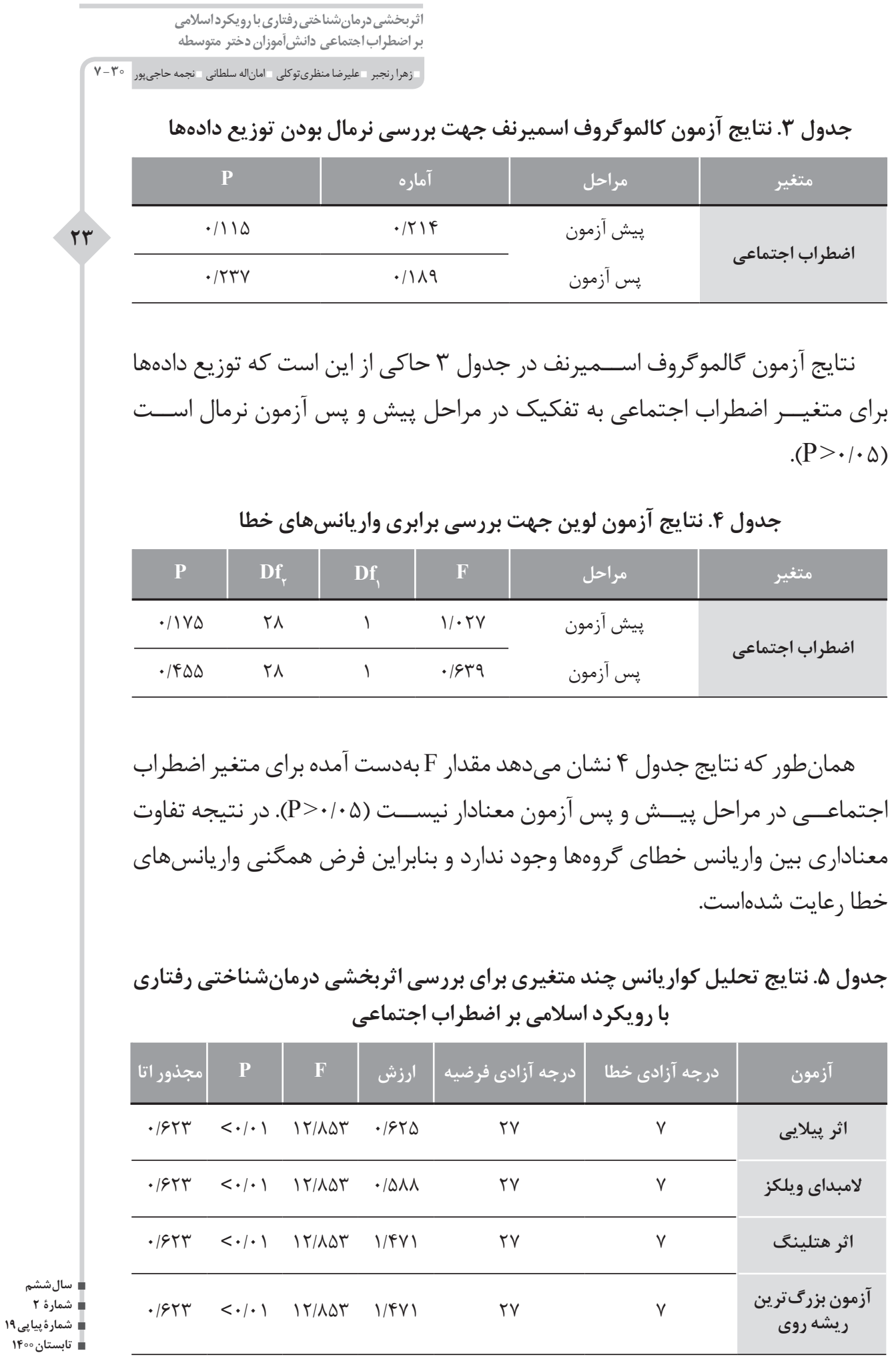


براى يى بردن به متغيرى كه بين دو گروه تفاوت معنى دار دارد، تحليل كواريانس جند متغيرى انجام شد. بر طبق نتايج جدول ه، بين آزمودنىهاى گروه آزمون و گروه كنتــــرل، از لحاظ متغير وابســته (اضطراب اجتماعى) تفــاوت معنى دارى وجود دارد

جدول 9. نتايج تحليل كوواريانس جهت بررسى تأثير درمانشناختى رفتارى با رويكرد

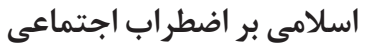

\begin{tabular}{|c|c|c|c|c|c|c|c|}
\hline | اندازه اثر & معنى سطارى & F & مجذنوراتين & آزادى & مجذوروات & شاخص & متغير \\
\hline \multirow{3}{*}{$\cdot / \pi \wedge$} & \multirow{3}{*}{$\cdot 1 \cdots 1$} & \multirow{3}{*}{$1 r / 9 V$} & $\Delta \wedge \Delta / \Delta q$ & 1 & $\Delta \wedge \Delta / \Delta q$ & بين گروهى & \multirow{3}{*}{ اختماعى } \\
\hline & & & $|f| / 9 \mid$ & rF & IFTF/QF & درون گروهى & \\
\hline & & & & $r_{\omega}$ & $r \cdot 1 \cdot / \Delta r$ & كل & \\
\hline
\end{tabular}

بـــا توجه به برقــرارى مفروضههاى تحليل كوواريانس، مى تــــوان از اين آزمون براى سنجش فرضيهها استفاده كرد. لذا، براى بررسى اثربخشى بسته آموزشى درمانشناختى رفتارى مبتنى بر رويكرد اسلام بر كاهش اضطراب اجتماعى دانشآموزان تحليل واريانس تك متغيرى استفاده شد.اين آزمون براى مقايسه گروه آزمايش و گروه گواه استفاده شد. جدول أ، نتايج تحليل كوواريانس را نشان مى عهد. نتايج جدول و، نشان مى دهد كه بين ميانگين نمرات يسآزمون متغير اضطراب اجتماعى دونى

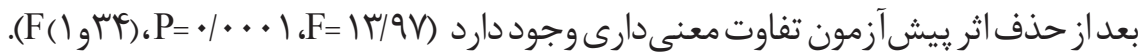
بنابرايسـن ميانگين نمرات يس آزمون گروه آزمايش بهطور معنى دارى در متغير اضطراب

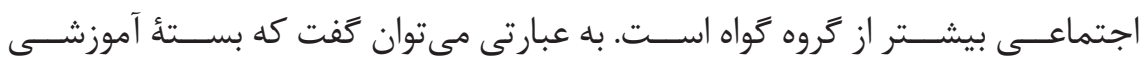
درمانشناختى رفتارى مبتنى بر رويكرد اسلام بهطور معنى دارى موجب كاهش اضطراب اجتماعى در مرحله يس آزمون شده است. 


\section{بحتق و نتنبيجلَيبرى}

هدف اين يزوهش بررســى اثربخشى درمانشـــاختى رفتارى با رويكرد اسلامى بر

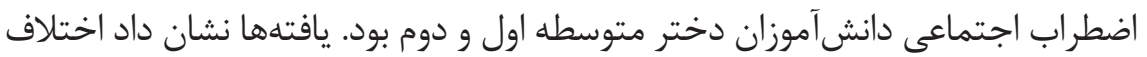

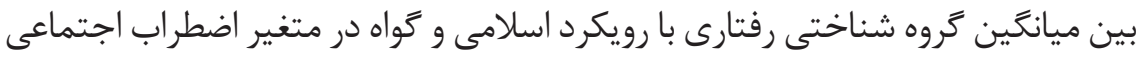

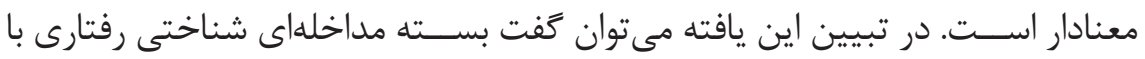

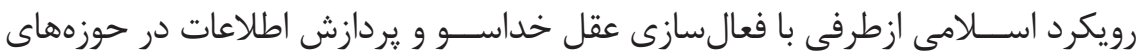

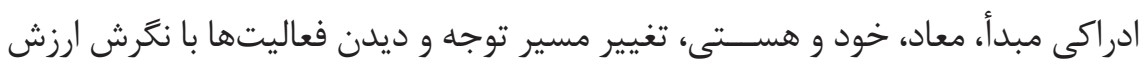

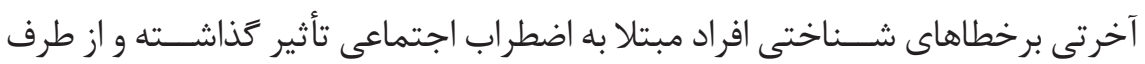

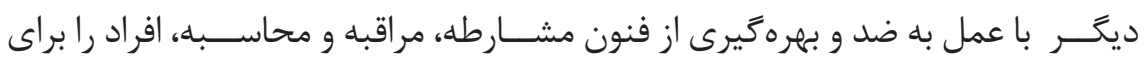

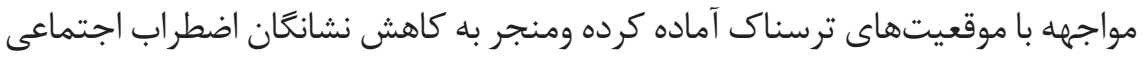

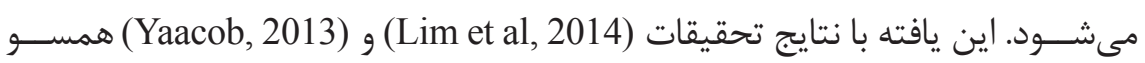

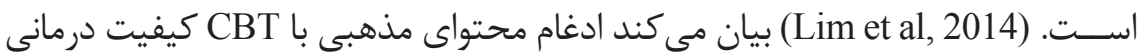

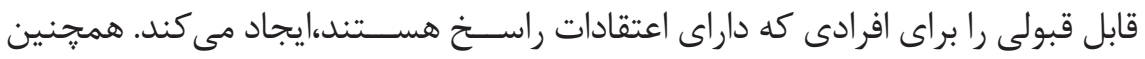

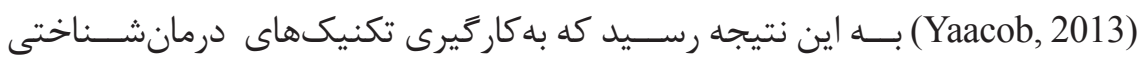

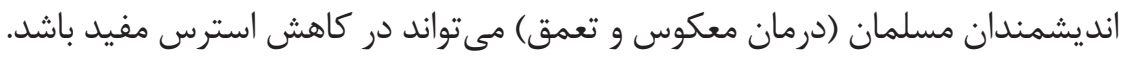

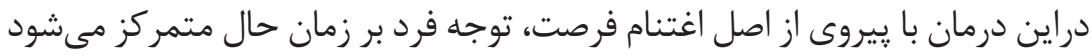

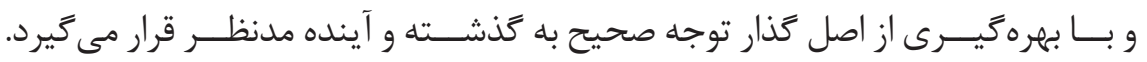

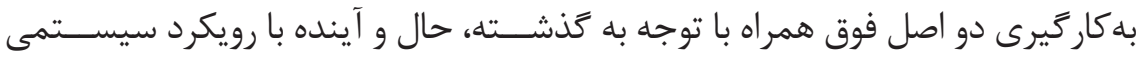

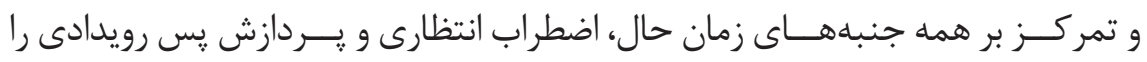

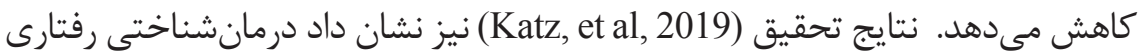

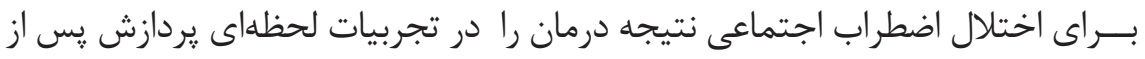

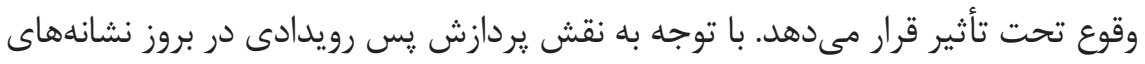

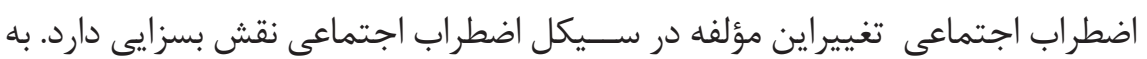

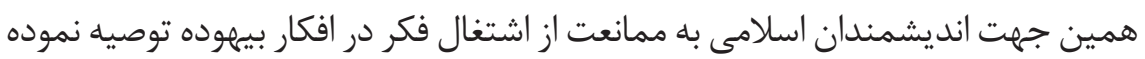

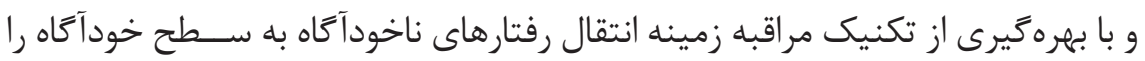

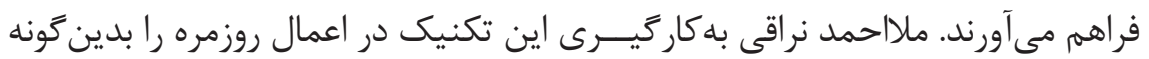

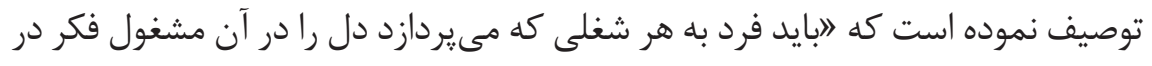


حكمتهاى خدا كند. مثلاً در حالت اكل به نظر بصيرت بنگَرد كه جگُونه خدا قوام بدن

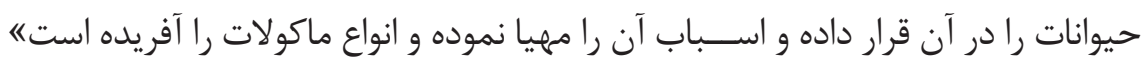

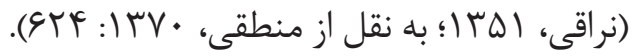

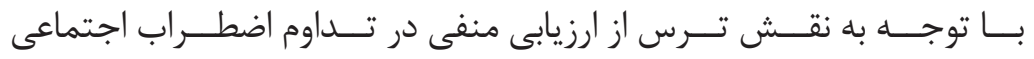

(Heimberg, et al, 2010) موحدانه مدنظر قرار گرفته واز طريق اعتقاد به حضور ناظر محترم، ترس از ارزيابى منفى در موقعيتهاى عملكردى كاهش مىيابد. بــا درك حضور ناظر محترم فرد درمى يابد خدا بر ضمير همه كس آَاه و به جميع افعالش بيناست. در اين رويكرد رابطه من- تو به مونه قاعده مثلثى تبديل مىشــود كه خداوند در رأس آن قرار دارد. در جنين شرايطى فرد با قراردادن ارتباط من ـ تو در يرتو مقصد و مقصود كلان هســتى، فضاى بزركترى را براى

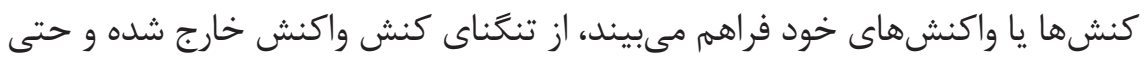
با دريافت نكردن واكنش از ناحيه ديگرى همجنان به كنش مى يردازد. يافتههاى تحقيق هاشمى و همكاران (و (1) نيز مؤيد اين موضوع است كه درمانشناختى رفتارى منجر به كاهش ترس از ارزيابى منفى و توجه متمركز بر خود در افراد مبتلا به اختلال اضطراب اجتماعى مىشود.

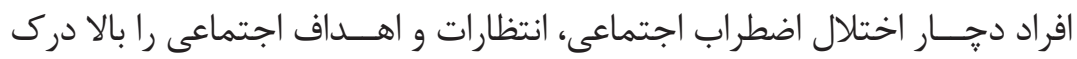

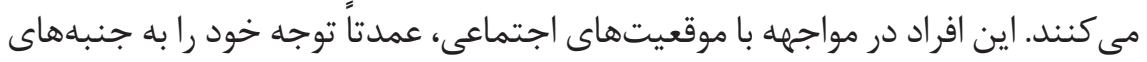
منفـــى معطوف مى كنـند. ايــن موضوع منجر به بيش بــــرآورد ييامدهاى منفى مواجهها اجتماعى، خودانعاره منفى بهعنوان يك موجود اجتماعى يا احســاس ضعف در مهارت اجتماعى مىشود. در نتيجه، اين افراد اشتباهات خود را فاجعهآميز تلقى مى كنند و فرار از اجتماع را انتخاب مى كنند (hofmann, 2007). در درمانشناختى رفتارى اسلامى مراجع مى آموزد كه آدميان از حيث فهمه و عمل،

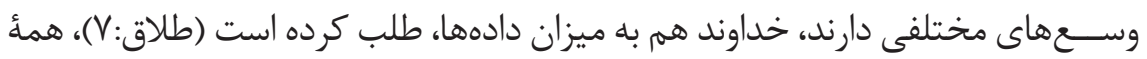

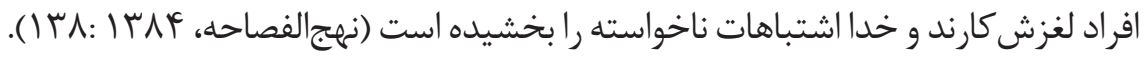
لذا هنگًام تعيين اهداف اجتماعى بر هماهنگَى سازى آن با معيارهاى شريعت و ظرفيت خود اقدام نموده و يس از انجام خطاهاى اجتماعى نخست به بازبينى مىيردازد و متوجه

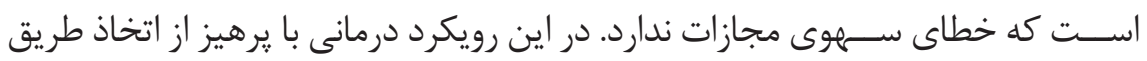


تكلف و انجام تكاليف متناســب با ظرفيت، با اجتناب كــهـ عامل تداوم بخش اضطراب اجتماعى است، مقابله مىشود.

تعيين اهداف اجتماعى ســـح بالا و اجتناب از موقعيتها درايجاد خودانغاره

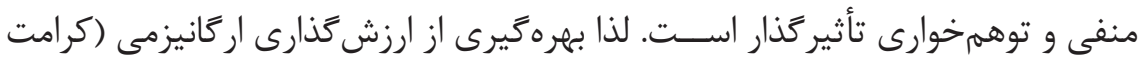

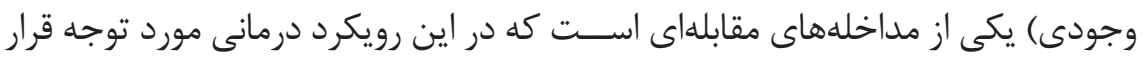

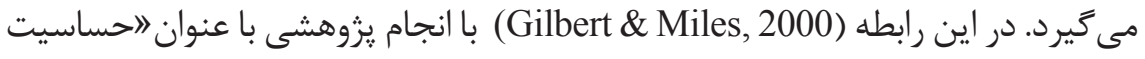
در برابر تنزل اجتماعى ( يا سركوب اجتماعى)" به اين نتيجه رسيدند كه تجربه انتقاد،

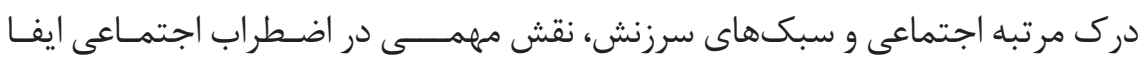

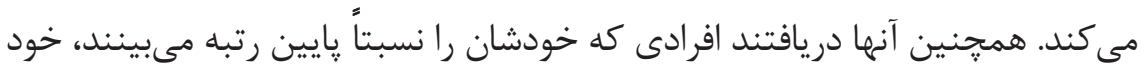

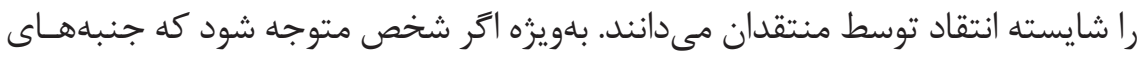

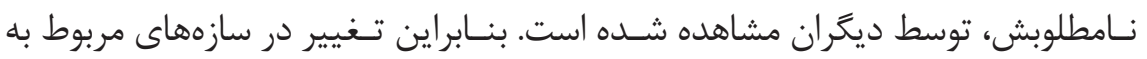

خود، كاهش اضطراب اجتماعى را بيشبينى ميى كند (Gregory \& Peters, 2016). بخش عمده اين رويكرد درمانى بهره

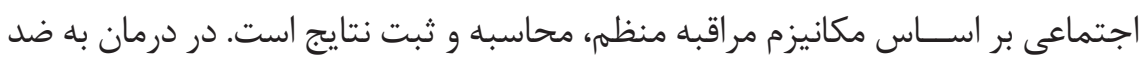

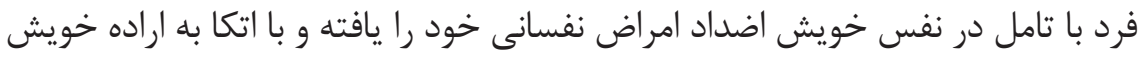

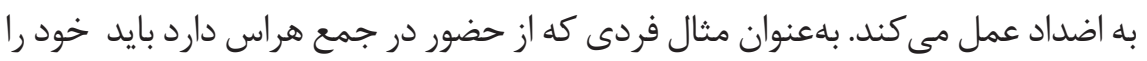

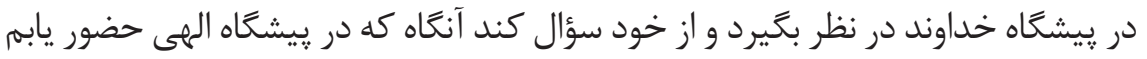

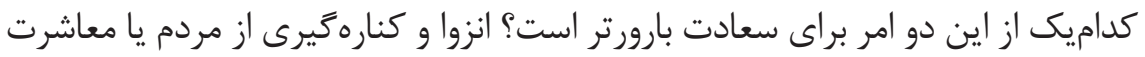

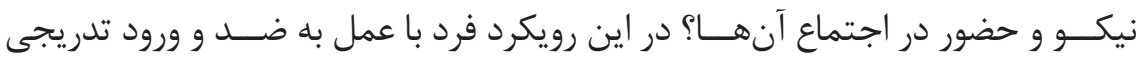

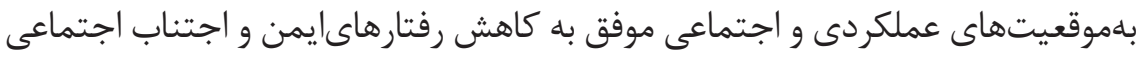

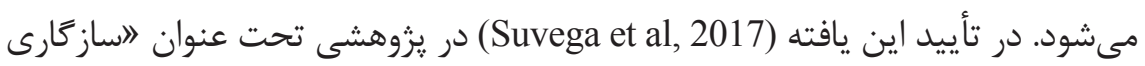

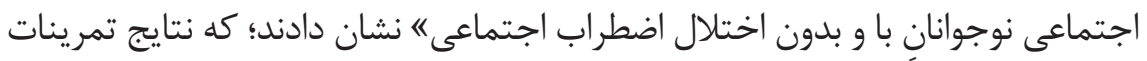

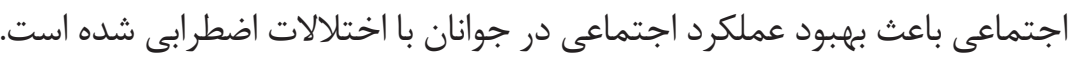

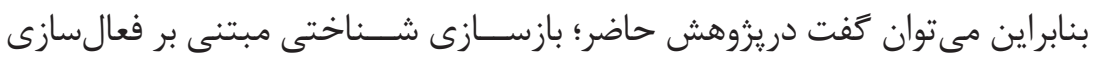

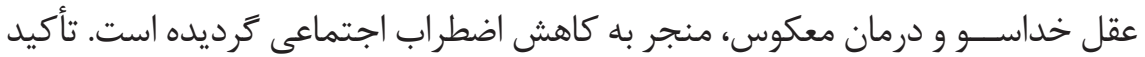

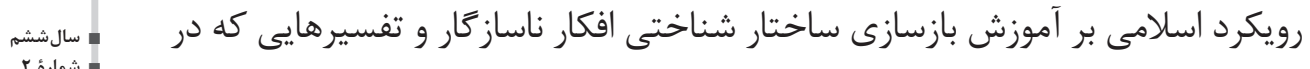

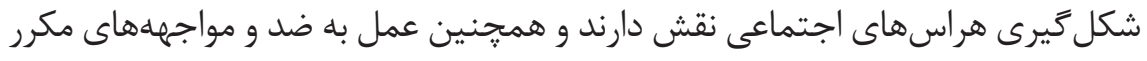


با موقعيتهاى هراسآور در جلســات درمانى، فرصتى را براى تجربه موفقيت در ارزيابى مجدد و خودكار آمدى فراهم مى كند. از سوى ديكر بررسى عادات ذهنى از جند إند منظر و

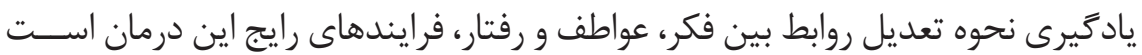
كه به نوبه خود كاهش اضطراب اجتماعى را در بردارد.

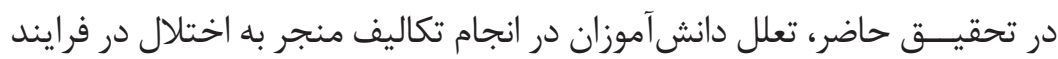

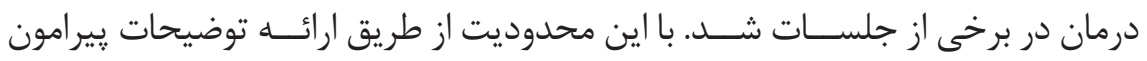
نقش تكليف در دسـتيابى به اهداف اين نوع درمان مقابله شد. همجنين دادههاى اين

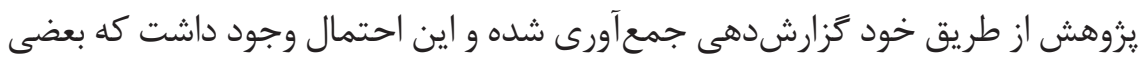

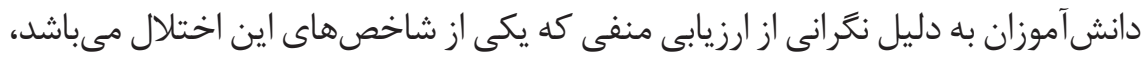

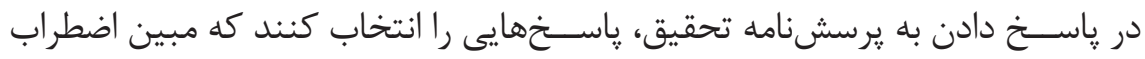
كمترى در آنان باشد. بــا توجه به يافتهاى يُوهش، درمانشـــاختى رفتارى با رويكرد اســلام بهعنوان يك رويكرد درمانى تلفيقـى و منطبق بر زمينه فرهنكى ـ مذهبى جامعه ايران، بلطور

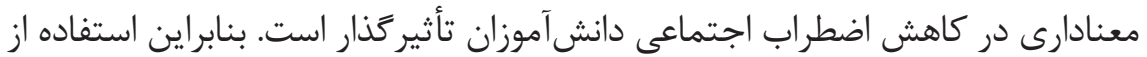
اين رويكرد درمانى اســلامى به روانشناســان، مشاوران و متخصصان امر تعليه و تربيت

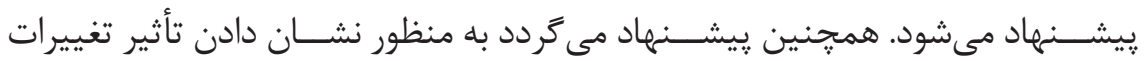

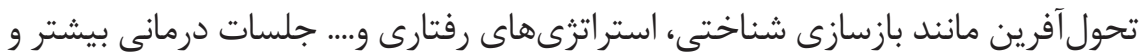
استفاده از يك دوره يى گيرى طولانىتر مدنظر قرار كيرد.

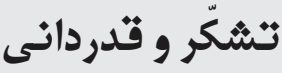

اين مقاله بركرفته از رساله دكترى نويسنده اول است. از تمامى دانشآموزان

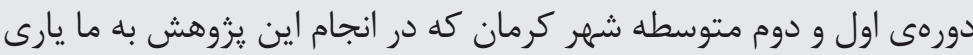

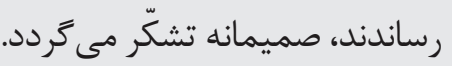




\section{منابع}

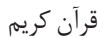

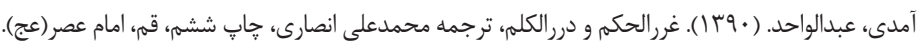

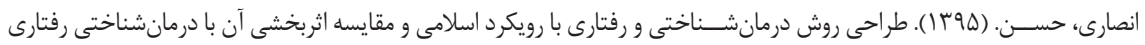

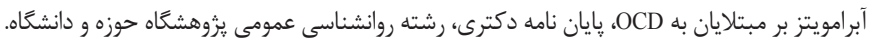

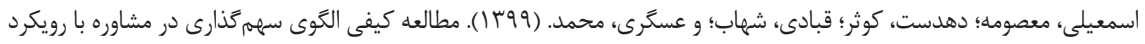

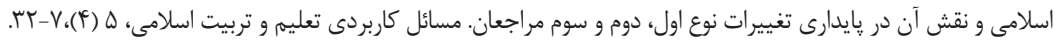

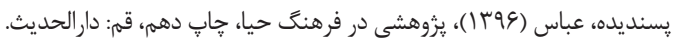

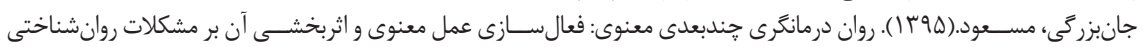

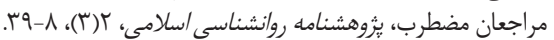

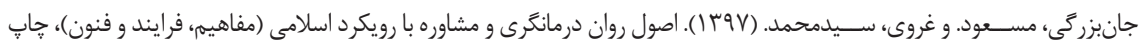

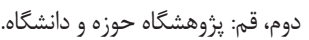

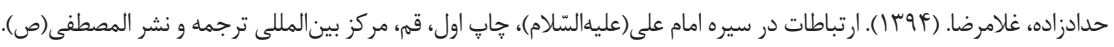

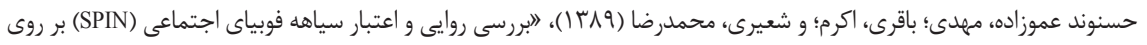

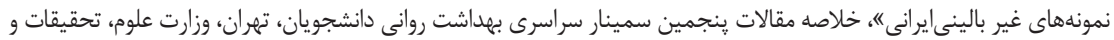

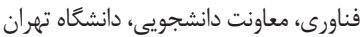

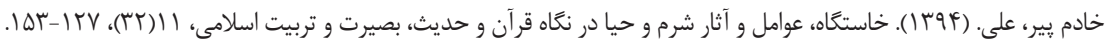

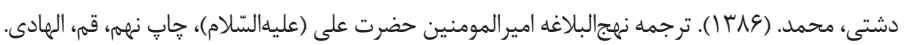

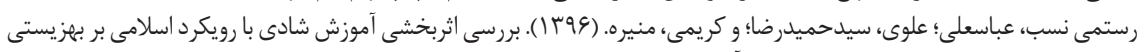

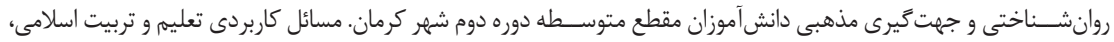

$.99-F V ،(Y) Y$

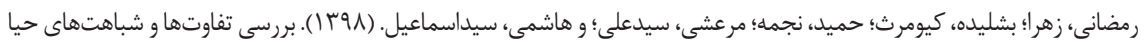

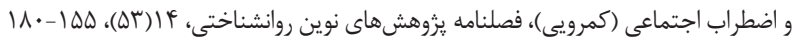

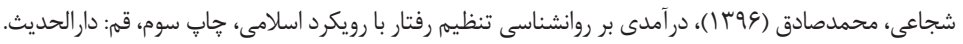

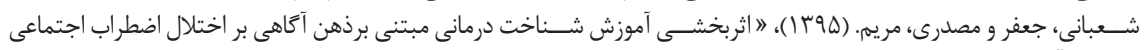

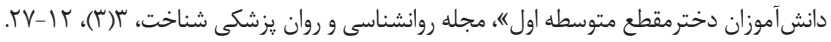

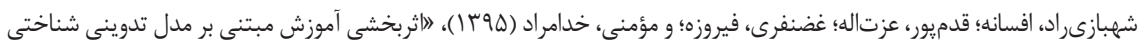

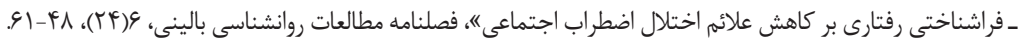

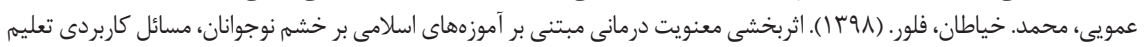

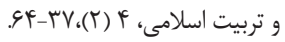

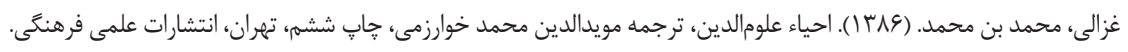

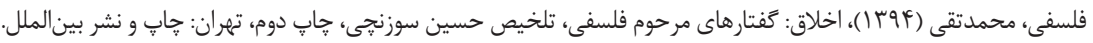

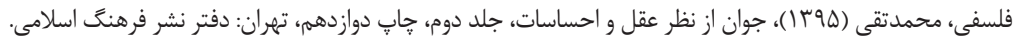

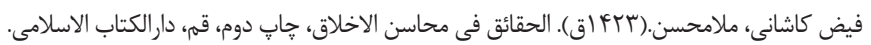

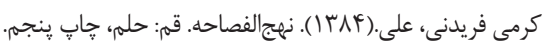

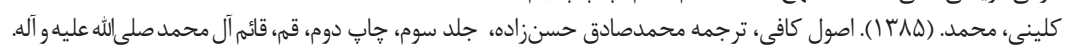

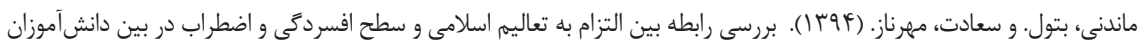

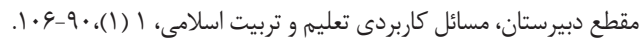

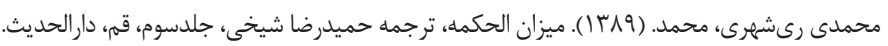

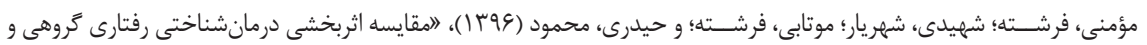

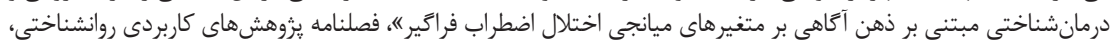

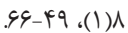

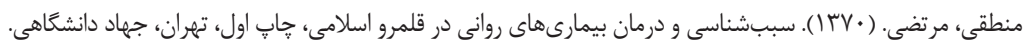

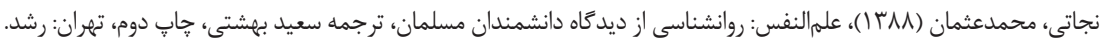

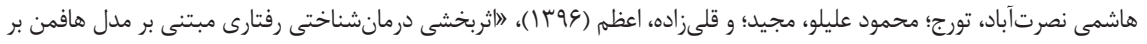

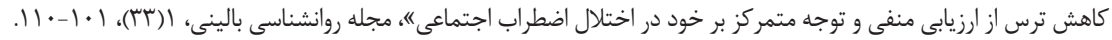


Connor, K.M., Davidson, J.R.T., Churchil, L.R, Sherwood, A., Foa, E., \& Weisler, R.H. (2000). Psychometric properties of the Social Phobia Inventory (SPIN): New self-rating scale, British Journal of Psychiatry, 176(4), 379-38.

Gilbert, p., Miles, J. N.V. (2000). Sensitivity to Social Put-Down: it's relationship to perceptions of social rank, shame, social anxiety, depression, anger and self-other blame, Personality and Individual DiFFerences, 29, 757-774.

Gregory,B.,Peters,L.(2016).Changes in the self during cognitive behavioral therap for social Anxiety disorder: ASystematic review,Clinical Psychology Review52,1-18,. Doi.org/ 10.1016/ j.cpr. 2016. 11.008 .

Heimberg,R.G., Brozovich,F.A.,Rapee,R.M.(2010). Chapter 15-A Cognitive Behavioral Model of Social Anxiety Disorder: Update and Extension,Social Anxiety (Second Edition)Clinical, Developmental, and Social Perspectives395-422 ,. https://doi.org/10.1016/B978-0-12-3750969.00015-8

Hofmann, S.G.(2007).Cognitive Factors that Maintain Social Anxiety Disorder: a Comprehensive Model and its Treatment Implications, Cognitive Behaviour Therapy, 36(4), 193-209. doi: 10.1080/16506070701421313

Katz, D.E., Cassin,S., Weerasinghe, R.,\&Rector,N.A.(2019). Changes in post-event processing during cognitive behavioural therapy for social anxiety disorder: A longitudinal analysis using post-session measurement and experience sampling methodology, Journal of Anxiety Disorders102-107, 66,. doi. org/10.1016/j.janxdis.2019.102107.

Lim, C., Sim, K., Renjan, V., Sam, H.F., LiQuah, S. (2014). Adapted Cognitive behavioral therapy for religious individuals with mental disorder, A Systematic review, 9, 3-12. Doi.org/10.1016/jajp.2013. 12. 011 .

Neufeld,C.B.,Palma,P.C.,Caetano,K.A.S.,Brust-Renck,P.G.,Curtiss,J.,\&Hofmann,S.G.(2019.A randomized clinical trial of group and individual Cognitive-Behavioral Therapy approaches for social Anxiety disorder,International Journal of Clinical and Health Psychology,20,29-37. doi.org/ 10.1016/j.ijchp. 2019. 11.004.

Nordgreen,T., Gjestad,R., Andersson,G., Carlbring , P.,\&Havik ,O.E.(2018). The effectiveness of guided internet-based cognitive behavioral therapy for social anxiety disorder in a routine care setting,Internet Interventions 13,24-29, doi.org/10.1016/j.invent.2018.05.003.

Richey,J.A,Brewer ,J.A ,Sullivan-Toole,H.,Strege,M.V.,Kim-Spoon,J.,White,S.W.,Ollendick T.H. (2019). Sensitivity shift theory: A developmental model of positive affect and motivational deficits in social anxiety disorder,Clinical Psychology Review101756,2019) 72 ,. https://doi.org/ 10.1016/j. cpr.2019.101756

Santoft,F.,Salomonsson,S.,Hesser, H.,Lindsäter,E.,Ljótsson,B., Lekander,M., Kecklund ,G., Öst ,L.G.,\&Hedman-Lagerlöf,E.(2019).Processes in cognitive behavior therapy for social anxiety disorder: Predicting subsequent symptomchange, Journal of Anxiety Disorders67,102-118, doi. org/10.1016/j.janxdis.2019.102118.

Suvega,C., Kingery, J.N., Davisa,M., Jones, A., Whitehead, M.,\& Jacob,M.L.(2017). Still lonely: Social adjustment of youth with and without social anxiety disorder following cognitive behavioral therapy, Journal of Anxiety Disorders72-78 ,52 ,. doi.org/ 10.1016/ j.janxdis. 2017.10.005

Yaacob, N.R.N. (2013). Cognitive therapy approach from Islamic Psycho-Spritiual Conception, 97, 182-187. Doi:10.1016/j.sbspro.2013. 10. 220.

Yuan,M., Zhu,H., Qiu,C., Meng,Y., Zhang,Y., Ren,Z., Li, Y.,Yuan, C., Gao, M., Lui,S., Gong, Q.,Zhang, W.(2017). Altered Regional and Integrated Resting-state Brain Activity in General Social Anxiety Disorder Patients before and after Group Cognitive Behavior Therapy,Psychiatry Research: Neuroimaging30-37,(2017)272, https://doi.org/10.1016/j.pscychresns.2017.12.004 